\title{
Forearc seafloor unconformities and geology: insight from 3D seismic geomorphology analysis, Peru
}

Gérôme Calvès ${ }^{1}$ (orcid.org/0000-0003-3829-131X), Constance Auguy ${ }^{1} \quad$ (orcid.org/0000-00031060-4425), Léopold de Lavaissière ${ }^{1}$ (orcid.org/0000-0002-3063-3103), Stéphane Brusset ${ }^{1}$ (orcid.org/0000-0002-7880-4514), Ysabel Calderon ${ }^{1,2}$ (orcid.org/0000-0003-1060-4425), Patrice Baby $^{1,2,3}$ (orcid.org/0000-0001-6142-5174).

${ }^{1}$ Université Toulouse 3, Paul Sabatier, OMP-GET, 14 avenue Edouard Belin, 31400-F, Toulouse, France.

${ }^{2}$ PeruPetro, Lima, Peru.

${ }^{3}$ Institut de recherche pour le développement (IRD).

Corresponding author: Gérôme Calvès (gerome.calves@get.omp.eu)

\section{Key Points:}

- Unconformities at forearc seafloor are associated with erosive power of oceanic bottom currents and/or wave action.

- The observed unconformity surfaces cover $18-100 \%$ of the seafloor at the studied sites.

- Estimates of sedimentation rate and paleo-productivity in such regions are assessed with regard to unconformities and hiatuses.

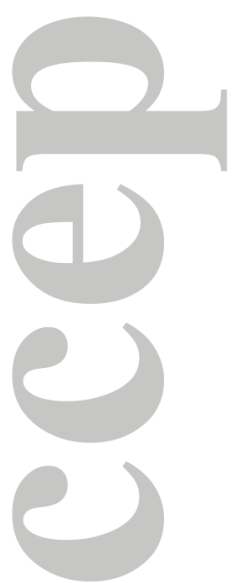

This article has been accepted for publication and undergone full peer review but has not been through the copyediting, typesetting, pagination and proofreading process which may lead to differences between this version and the Version of Record. Please cite this article as doi: 10.1002/2017G C 007036 


\section{Abstract}

New 3D seismic data collected over $4870 \mathrm{~km}^{2}$ in the $3^{\circ} 45^{\prime}-12^{\circ} 30^{\prime} \mathrm{S}$ Peruvian segment of the East Pacific subduction system image seafloor erosional surfaces that can be mapped across the forearc basins. Forearc basins experience various stresses, from their base where basal tectonic erosion acts to the seafloor which is influenced by aerial, shallow and deep water currents driven by waves or thermohaline oceanic currents. Previously there has been little interest in stresses on the upper layer and there is a lack of documentation of unconformities and the erosive processes in certain bathymetric domains in forearc basins. We address this with the study of examples sourced from 3D seismic reflection surveys of the seafloor offshore Peru. Unconformities occur in two distinctive bathymetric domains associated with the continental shelf and the upper slope of the margin. Identification and characterization of unconformity surfaces yield estimates of the amount of erosion at the modern seafloor that range from 18 to 100\%. Regional physical oceanography allows us to calibrate potential candidates for these two distinctive domains. The first control on erosion is the dynamics of deep to intermediate oceanic currents related to the Humboldt-Peru Chile water masses, while the second is wave action in the shallower erosional surfaces. This study illustrates the unseen landscape of the forearc basins of South America and helps to highlight the importance of erosive surficial processes in subduction landscapes.

\section{Keywords:}

Forearc basin, seafloor, 3D seismic reflection, seismic geomorphology, discontinuities, unconformities, erosion, Humboldt Peru-Chile current, Peru.

\section{Introduction}

Marginal systems offshore continents have for a long period of time been documented as depositional systems with limited attention to the unconformities observed on the continental shelf and their erosion-related processes [Blackwelder, 1909; Cotton, 1918; Hay, 2015; Miall, 
2016; Vail et al., 1980]. Another important aspect is the dynamics of erosion of fine grained sediments that has not yet been fully understood [e.g., McCave, 1984]. The context of strong erosion from on- to offshore has been rarely studied and quantified. As an example, the offshore domain of the rising orogenic island of Taiwan has been well documented, although constraints on submarine erosion and its forcing mechanisms have not been clearly understood [Ramsey et al., 2006]. Along the Pacific margin of North and South America, coastal erosion has been mainly investigated at rocky shores where paleo-shorelines emerge or drowned, as a result of various uplift events [e.g., Shepard and Grant, 1947; Clift and Hartley, 2007; Saillard, et al., 2009; Jara-Muñoz et al., 2017]. Various cyclic stresses affect the margin in these places. The two most important are: waves sourced by the strong westerly winds in the Southern Ocean [Beccario, earth.nullschool.net; López, et al., 2015] and along-margin oceanic currents such as the Peru-Chile (Humboldt) Currents [Chaigneau et al., 2013] (Figure 1). Sediment archives at the seafloor from 3 to $18^{\circ} \mathrm{S}$ are characteristic of current-dominated regimes [Reinhardt, et al., 2002] with ongoing phosphorite formation, tide-topography interaction and resultant non-linear internal waves [Erdem et al., 2016]. Mooring experiments documented current speeds of up to $20 \mathrm{~cm} / \mathrm{s}$ in the upper $200 \mathrm{~m}$ of the continental shelf of Peru from $5^{\circ} \mathrm{S}$ to $15^{\circ} 30^{\prime} \mathrm{S}$ [Brockmann, et al., 1980].

Continental shelves offshore South America are an important region for the study of resources and the interactions of atmospheric and oceanographic processes in solid Earth sciences. Peruvian forearc basins (Figure 1) [Dickinson, 1995; Noda, 2016] have been imaged using sub-bottom profilers and multibeam echosounders [Reinhardt, et al., 2002] during research cruises and sampled by dredges, shallow piston cores, the Ocean Drilling Program [e.g., Suess et al., 1988], and by oil and gas exploration wells. Most of the academic geoscientific work on 
Peruvian forearc basins has been performed offshore in the deep water domain ( $>200 \mathrm{~m}$ water depth). This has allowed understanding of the distal part of the margin and its relationship with the subducting plate, in the area of the trench to the upper slope. Structure and infill have been studied using 2D seismic reflection surveys [e.g., Thornburg and Kulm, 1981; Kulm et al., 1982; Moore and Taylor, 1988]. The structural framework of the margin and forearc basins worldwide has been divided into two types, with one related to subduction accretion and the second to basal tectonic erosion [e.g., Clift et al., 2003; Clift and Vannucchi, 2004] (Figure 2). Many subsurface discontinuities have been studied in order to document subsidence and basal erosion of accretionary margins [e.g., Scholl et al., 1980; von Huene and Lallemand, 1990]. The oldest basal unconformity identified in forearc basins is related to the interface between the structurally active or passive basement of the overriding plate within the context of the subduction zone (Figure 2). The subsequent unconformities within the forearc stratigraphy then depend on the vertical movements and the source of sediments (volcaniclastic, siliciclastics, and in-situ produced carbonates) and record erosional events and hiatuses depending on the rates of sedimentation. Unconformities at the seafloor are one of the least recognized and documented surfaces in the evolution of forearc basins.

Seismic technology has advanced in the third dimension [Cartwright and Huuse, 2005], thus allowing sedimentary basins to be assessed with an unprecedented level of detail. Threedimensional seismic data can be used to study sub-seafloor geology in detail, such as that observed by high-resolution bathymetry [Bulat, 2005; Grant and Schreiber, 1990]. Seafloor features offer a window to the deeper subsurface of a given sedimentary basin and so resolve Earth surface processes identified from preserved features [Bourgeois et al., 1988; Sosson et al., 1994; Collier et al., 2006; Gupta et al., 2007; Huuse, 2011; Mitchell et al., 2013]. The seafloor 
bathymetry, combined with deep penetration seismic reflection surveys, is commonly used to document the mechanical and tectonic behavior of accretionary margins [e.g., Beaudry and Moore, 1981; Gulick, et al., 2010; McNeill and Henstock; 2014; Frederik, et al., 2015], but is rarely used to constrain external forces acting on the top of the margin slope.

The Peru offshore domain represents an area of 900,000 km² of which $82,000 \mathrm{~km}^{2}$ are associated with the continental shelf. The offshore domain, its water column conditions and seafloor habitat of a major interest to those concerned with fish populations in the Peruvian upwelling ecosystem [Gallardo 1977; Arntz et al., 1991]. The importance of bathymetric information has been shown along the Peru margin not only for Earth sciences, but also for life sciences. Limited knowledge on shallow bathymetric environments south of $10^{\circ} \mathrm{S}$, i.e. the morphology of the continental shelf, is key to models of water column biological processes and prevents an understanding of how sediments $(\mathrm{Fe})$ contribute to the development of phytoplankton [Echevin et al., 2008]. The only seafloor erosion documented on 2D seismic reflection grid offshore Peru and potentially related to bottom currents has been done by Ballestros et al. (1998) for water depth greater than $2000 \mathrm{~m}$ in the Yaquina and Lima sedimentary basins [Clift et al., 2003].

Our aim is to document the present-day seafloor bathymetry, acoustic properties and geology in the near subsurface using 3D seismic reflection data from four sedimentary basins off the coast of Peru. From North to South these basins are named: Tumbes, Talara, Salaverry, and Pisco (Figures 1 and 2). Our specific interest is in the identification of constructive and destructive surfaces that record the seafloor of these forearc basins. 
111

112

113

114

115

116

117

118

119

120

121

122

123

124

125

126

127

128

129

130

131

132

133

134

\section{Data and methods}

Our seismic data set covers most of these forearc basins, covering a bathymetric range of 20 to $2040 \mathrm{~m}$, in the offshore Peru area (Figures 1 and 3). The data used for the current study are 3D multi-channel, post-stack, time-migrated reflection seismic data. They were acquired within exploration areas offshore Peru and are named based on these hydrocarbon exploration license numerations. The seismic data displayed in this study are zero phase and have the Society of Exploration Geophysicists (SEG) normal polarity, i.e. black peak indicating an increase in acoustic impedance. We use seismic attributes to enhance sedimentary to structural features that occur from the seafloor to the subsurface. The seismic attributes are extracted from the two-way time horizon mapped within the 3D seismic reflection data. We use a constant velocity (1500 $\mathrm{m} / \mathrm{s}$ ) for depth conversion of the seafloor from time to depth domain. The details of each seismic data set and seafloor surfaces are summarized in Table 1. The 3D seismic data in this study have been interpreted using standard seismic stratigraphic techniques [Mitchum et al., 1977; Vail et al., 1977] and seismic geomorphology principles [Posamentier et al., 2007] based on reflection terminations and seismic facies reflection characteristics. The seafloor reflection can show concordance (no termination) or truncation (erosional or structural). The seafloor reflection and surrounding reflections are interpreted as a sequence boundary [Mitchum et al., 1977]. The vertical resolution of the shallow section of the six seismic cubes range is 8 to $12 \mathrm{~m}$. With this vertical resolution, the near-seafloor 3D seismic provides stratigraphical and geomorphological insights into the architecture that would normally be sub-seismic scale in the deeper subsurface [Steffens et al., 2004].

Oceanographic data (temperature, salinity, wave observations) are sourced from National Oceanic and Atmospheric Administration (NOAA) world ocean database (WOD13, Station 7538849(C)) [Boyer et al., 2013] and the NOAA National Data Buoy Center (Station 32012 - 
Woods Hole Stratus Wave Station, data from 2007 to 2015) (http://www.ndbc.noaa.gov). We have converted the wave frequency to wavelength using the deep-water gravity equation [Lamb, 1994]: $\lambda=\mathrm{g} /\left(2 \pi f^{2}\right)$, where $\mathrm{g}$ is gravitational acceleration and $f$ is the wave frequency measured in Hz. The depth of penetration of wave action (i.e. capacity to entrain sediment at the mudline interface) is defined as one half of its wavelength [Reading and Collinson, 1996].

\section{Results}

\subsection{Seafloor bathymetry and morphology}

Observed features at the seafloor from $3^{\circ} 45^{\prime} \mathrm{S}$ to $12^{\circ} 30^{\prime} \mathrm{S}$ span two main morphological domains: the shelf and the upper slope (Figures 1 and 3, Table 1). In the Tumbes Basin (Z1 and Z38; Figures 3a and 3b), the seafloor dips from NE to SW over a depth range from about $20 \mathrm{~m}$ to $1380 \mathrm{~m}$ within the area surveyed by 3D seismic data. The mean slope is gentle and ranges from 2.6 to $3.6^{\circ}$. Local increases in slope are related to structural features (see below). Along the margin the Talara Basin (Figures 1, 3c and 3d) is covered by two 3D seismic surveys. The seafloor dips from E to W, with a depth range from 190 m to 2040 m, within the area surveyed by $3 \mathrm{D}$ seismic data. The mean slope is moderate and ranges from $\sim 6$ to $10^{\circ}$. In the northern area (Z34A; Figure 3c) the upper slope shows a steep margin deepening to a smooth flat seafloor surface. In the southern area (Z34E; Figure 3d) the shelf extends as a low angle surface that marks the shallower part of the upper slope that evolves to an incised deep and steep topographic depression that runs along an east to west axis. These two depressions are related to two deep water canyons named La Bocana and Paita (Figure 3d). These two canyons have not yet been surveyed. They are named from the nearest towns along the coast and are located north of the Chiclayo Canyon $\left(7^{\circ} \mathrm{S}\right)$ described by Sosson et al. [1994]. Further south in the Salaverry Basin (Z35; Figure 3e), the seafloor dips from ENE to WSW over a depth range from $~ 110 \mathrm{~m}$ to 200 
$\mathrm{m}$ within the area surveyed by $3 \mathrm{D}$ seismic data. The mean slope is low, with a value of $1.75^{\circ}$. The last surveyed area is within the Pisco Basin (Z33; Figure 3f). The seafloor dips from NE to SW with a depth range from $\sim 100 \mathrm{~m}$ to $\sim 320 \mathrm{~m}$ within the area surveyed by 3D seismic data. The mean slope is low with a value of $1^{\circ}$. Features observed at the seafloor are summarized in Table 2. We first describe unconformities at the seafloor of each sedimentary basin/data set from North to South along the Peruvian offshore domain, after which we document other preserved features.

\subsection{Seafloor unconformities}

\subsubsection{Tumbes Basin seafloor unconformities}

Observed seafloor unconformities in the Tumbes Basin seismic reflection data (Figure 4a) are related to five different configurations. The first configuration is associated with toplap termination with a high angle dipping into subsurface sequences structured by faults (Figure 4b). This is well marked by seismic amplitude changes and abrupt changes over the discontinuity towards the north of the study area. These structures occur in the shallower domains of the study area. The unconformities cover extensive areas from $10 \mathrm{~km}^{2}$ to over $100 \mathrm{~km}^{2}$ (Figure 4c). The second configuration is related to lower angle toplap terminations that are prolonged by continuous reflections that extend seaward (Figure 4d). The third is also associated with lowangle toplap terminations that in this area are prolonged over short distances and closed loop by other toplap terminations and an undulating high amplitude erosional truncation (Figure 4d). These mark mounded structures over areas of 30 to $>40 \mathrm{~km}^{2}$ located in the SW of the study area (Figure 4c). The mounded structures have a long axis orientated NNE-SSW, with a length $>2$ $\mathrm{km}$, an amplitude of $20 \mathrm{~m}$ and a wavelength of $0.4-1.0 \mathrm{~km}$. These structures are restricted to water depths $>200 \mathrm{~m}$. We interpret them as contourite drifts. These features are observed in area 
Z38 (Figure 5a). The seafloor seismic reflection amplitude map shows important variations, from continuous high amplitude to localized linear to rounded low amplitude areas (Figure 5b). The fourth configuration is associated with high angle toplap terminations that are associated with flat top erosional truncations (Figure 5c). One example is the Banco Peru that is located in the western part of the Tumbes Basin. These structures occur over local highs that show a different level of flatness. They show low to moderate amplitude values compared to the surrounding concordant higher amplitude seafloor reflections (Figure 5b). These erosional unconformities extend over areas $>10 \mathrm{~km}^{2}$. They are expressed in a wide range of bathymetric domains (Figures 5c and 5d). The fifth and last configuration of erosional unconformities at the seafloor in the Tumbes Basin is characterized by toplap high angle, with faulted underlying sequences that are rounded and positive mounds onlapped by surrounding continuous, younger seismic sequences (Figures 5c and 5d). They are related to tectonically uplifted structures that have been previously eroded under other conditions. Between all these various types of unconformities, $44 \%$ of the seafloor surface of the Tumbes Basin is subject to erosion (Table 2).

\subsubsection{Talara Basin seafloor unconformities}

The observed unconformities at the seafloor seismic reflections in the northern part of the Talara Basin (Z34A; Figure 6a) are related to seven different configurations. The seafloor amplitude shows a range of values, with low values associated with steep slopes and higher amplitude values related to concordant reflections at the seafloor (Figure 6b). The similarity attribute shows extensive areas of highly continuous reflection (Figure 6c). The first configuration of unconformities is associated with toplap termination with low angle reflections that are bounded in their opposite direction by other toplap terminations that also mark erosional truncations (Figure 6d). The unconformity ranges from 15 to $36 \mathrm{~m}$ in height (Figure 6d). This configuration 
204 is interpreted as the flank of a detached drift contourite, and its steep, eroded slopes. A second

205 configuration is associated with toplap terminations that are associated with steep relief of a

206 minimum 80, ranging up to $150 \mathrm{~m}$ that marks a scarp or an escarpment (Figures $6 \mathrm{~b}$ and $6 \mathrm{~d}$ ). This

207 scarp is associated with removal of material downslope in relation to mass wasting processes.

208 The third configuration is associated with low similarity and low reflectivity acoustic basement

209 outcropping at the seafloor. This type is localized at the transition from the high angle slope of

210 the margin and the lower basin fills (Figures 6c and 6d). The fourth and fifth show toplap

211 terminations and erosional unconformities related to incisions, such as channels or canyons in the

212 slope. These channels or canyons (Figures 6a and 7a) incise the seafloor from $40 \mathrm{~m}$ up to $360 \mathrm{~m}$

213 respectively along their walls that have lower amplitude reflection strength compared to basal

214 infill and inter-canyon deposits (Figures 6b and 7b). Two deep-water canyons are observed in the

215 southern part of the Talara Basin. These canyons are named Paita and La Bocana. The sixth

216 configuration is associated with low angle seaward toplap termination and erosional truncation in

217 the upper slope over a bathymetric range of 1400 to $400 \mathrm{~m}$ (Figure 7a). These are strictly

218 associated with erosive surfaces and do not contain depositional features. The seventh and last

219 configuration observed at the Talara Basin seafloor marks an extensive erosional unconformity

220 that shows high angle reflections associated with faults and tilted blocks (Figures 7c and 7d). The

221 surficial average unconformity covers 36\% of the area within the 3D seismic survey (Table 2).

222

223

224

225

226

\subsubsection{Salaverry Basin seafloor unconformities}

The observed seafloor unconformity in the Salaverry Basin (Z35; Figure 8a) is related to one configuration over two different types of sedimentary structures. The complete surface is associated with toplap terminations of various angles that mark the subsurface geology. The overall basin is truncated at the seafloor and highlights the sedimentary basin infill. Faults are 
expressed at the seafloor in the western part of the survey (Figure 8b). The eastern seismic reflections and sequences are tilted with an overall synclinal structure (Figures 8c and 8d). Truncated seismic structures outcropping at the seafloor are related to canyons infills or prograding clinoform sets (Figures $8 \mathrm{~b}$ and $8 \mathrm{~d}$ ). The surficial unconformity covers $100 \%$ of the area surveyed by 3D seismic data (Table 2). This is the highest surficial erosion observed along the entire Peru Margin.

\subsubsection{Pisco Basin seafloor unconformities}

The observed unconformity at the seafloor seismic reflection in the Pisco Basin (Z33; Figure 9a) is related to one configuration of sedimentary structures. The seafloor reflection surface has various amplitude values (Figure 9b) and associated with concordant, toplap termination reflections with low angle and erosional truncation (Figure 9c). The erosional truncation cuts a progradational sequence (Figures $9 \mathrm{~b}$ and $\mathrm{d}$ ) that is incised by linear to convergent seaward channels. This unconformity occurs over a bathymetric range of 125-160 m. The surficial unconformity covers $29 \%$ of the surveyed area by 3D seismic (Table 2). This marks the highest preserved depositional area within the regions studied offshore Peru.

\section{3 seafloor fluid flow features}

Within the surveyed area, a number of non-sedimentary features have been identified at the seafloor reflection. Localized small-scale seafloor depressions in the Tumbes and Talara Basins are pockmarks (Figures 5 and 6), related to fluid escape through underlying vertical gas chimneys. These are spatially located above reversed-polarity reflections (relative to the seafloor) known as bottom-simulating reflections (BSRs) that are commonly associated with free gas trapped beneath a layer of methane hydrate-bearing sediment. They are related to the occurrence of a velocity and impedance contrast related to the hydrate-bearing layers. 


\section{Discussion}

\subsection{Morphological features of unconformities} With observations of seafloor unconformities from different latitudes and depths along the Peruvian forearc basins, we identify potential processes related to these features. A synthetic diagram illustrates the occurrence of unconformities (Figure 10). Unconformities are observed in the two investigated domains, the shelf and upper slope. In the northern part of the Peruvian margin, these two domains express various types of erosive surfaces. As far south as $5^{\circ} \mathrm{S}$ in the Talara Basin (Figure 1) unconformities occur at two different levels/water depths along the upper slope: one shallow ( 200-300m) and one deeper ( 900-1100 m) (Figure 10). South of 5S the unconformities are observed at the shelf/upper slope transition as well as deeper water 300 m. Krissek et al. [1980] and Reiners and Suess [1983] documented the absence of sedimentation at the shelf break north of $10^{\circ} 30^{\prime} \mathrm{S}$ and south of $15^{\circ} \mathrm{S}$. A water depth of $200-300 \mathrm{~m}$ corresponds to the transition from the upper to intermediate water masses. Unconformities occur south of $5^{\circ} \mathrm{S}$ (Figure 10), as well depicted in the Salaverry Basin $\left(8^{\circ} \mathrm{S}\right)$ where the seafloor is recognized as being a continuous unconformity (Figure 8).

\subsection{Seafloor and physical oceanography interaction}

The primary surficial water mass movements within the study area are the action of oceanic waves sourced from far field activity in the Southern Ocean as well as waves generated by local southerly winds in the Eastern Pacific Ocean bordered by the Andes (Figure 1). The wave action is expressed by a wave base depth of penetration with two modes, the first peak at $55 \mathrm{~m}$ and the second at 150 m water depth (Figure 10) as recorded by buoys offshore Peru (Station 32012 Woods Hole Stratus Wave Station, data from 2007 to 2015) (http://www.ndbc.noaa.gov). The frequency and depth of action associated with these waves are surficial and decrease drastically as the seafloor depth increases. 
275 Currents (Figure 1) [e.g., Chaigneau et al., 2013; Czeschel et al., 2015]. These currents have the strength to displace and remove significant amounts of sediment and generate unconformities at the seafloor (Figure 10). In some places, deep water currents might induce a strong shearing momentum at the seafloor where they interfere. Such configuration is observed along the Peru margin when the Peru-Chile Undercurrent (PCUC) and Chile-Peru Deep Coastal Current (CPDCC) occur together (Figure 1). The prime example in this study is in the Salaverry area (Figure 11) where we have observed the most complete unconformity. Where only deep currents erode the seafloor, the magnitude of the unconformity decreases such as that seen in the Pisco Basin. This place has a counter part with an important coastal upwelling and high production rate of sediments [Krissek et al., 1980] that might balance the unconformity expression.

In the northern part of the Peruvian margin in the Tumbes and Talara Basins, we identify important erosion surfaces that are expressed in the water depth range of the surfaces currents, such as the Ecuador-Peru Coastal Current (EPCC), and the associated subsurface currents, e.g., the Equatorial Undercurrent (EUC) (Figures 10 and 11) [Chaigneau et al., 2013]. The complex seafloor geometry of bathymetric highs in the Tumbes Basin might cause the strength of the currents to increase and accelerate at these localities, focusing the erosion (Figure 5). The presence of moats and contourite drifts in bathymetric domains over $600 \mathrm{~m}$ water depth (Figures 5, 6 and 7) is diagnostic of a potential strong active bottom current associated with the Northward-spreading Antarctic Intermediate Water (AAIW) and the Pacific Central Water (PCW) [Tsuchiya and Talley, 1998]. In the Tumbes Basin, Banco Peru (Figure 1) is an isolated structural high that has a flat top platform in water depths of $100 \mathrm{~m}$ (Figure 5) and is subject to wave action that can be as deep as $300 \mathrm{~m}$ offshore Peru (Figure 10). Further east, towards the 
shore, these same waves can surge and stress the seafloor; this is highlighted by the strong erosional unconformity surface that is observed from $200 \mathrm{~m}$ up to $26 \mathrm{~m}$, at the shallowest limit of the surveyed area (Figure 4). The complex interaction between wave action and oceanic currents plays an important role in the near-coastal circulation and upwelling system of Peru [e.g., Pietri et al., 2014].

These unconformities might not be related to a single period of stress but instead are a combination spanning long periods of time, as suggested by sedimentary archives offshore Peru preserved in a bathymetric range of 90 to $1300 \mathrm{~m}$ and latitudes from 3 to $18^{\circ} \mathrm{S}$ [Erdem et al., 2016]. Along the Chilean margin at $40^{\circ} \mathrm{S}$ strong shelf currents sweep all fine-grained material [Hebbeln et al., 2001]. Sediments are channelized directly into the deep sea trench through the numerous canyons [Moberly et al., 1982; Hagen et al., 1994]. Further south in Chile the same observations and processes are shaping the seafloor of the offshore prism [Bernhardt et al., 2015 and 2016]. We have direct evidence of this on the slope of Talara Basin, with lobes at the mouth of deep-water canyons (Figure 6). Deep-water sedimentation in this area is associated with contourite drifts (this study) and suggests possible contributions from oceanic currents as conveyors of particles to the deep-water sediments along the margin [Muñoz et al., 2004]. An important goal remains to identify the action and erosive power of deep water currents downslope in the least studied water depth range of the upper slope. This is not investigated or quantified by physical oceanography studies along the upper slope of the Peru margin $>1000 \mathrm{~m}$.

4.3 Seafloor basin dynamics: depositional dynamics The identification of unconformities at the edge of significant packages of sediment, such as canyons and/or contourite drifts in the upper slope of the Peru margin show the importance of 
lateral sedimentation along such margins outside the continental shelf (Figures 5, 6, 7). The continental shelf has been the focus of numerous studies over the past decades in relation with upwelling [Suess, 1980; Shipboard Scientific Party, 1988] and accretionary/forearc basin genesis [e.g., Thornburg and Kulm, 1981; Ballesteros et al., 1988; Clift et al., 2003]. Careful estimates of deposition and erosion in such sedimentary basins could have an important role in calibrating sediment budgets and flux [Clift and Vannucchi, 2004; Stern, 2011], and/or syntectonic sedimentation history [Simpson, 2010; Vannucchi, et al., 2016] in a subducting geodynamic framework. Regional estimates of recent sedimentation rates underline these limitations in such settings [Muñoz et al., 2004]. In the Lima and Pisco Basins (Figure 1), Ocean Drilling Program Sites 679, 680, 681, 686 and 687 documented important discontinuities at the seafloor or in the subsurface, with numerous hiatuses spanning the last 11 m.y. [e.g., Shipboard Scientific Party, 1988; Ballesteros et al., 1988]. Buried unconformities in accretionary prisms are used to infer the evolution of the subduction factory. The occurrence of regional unconformities must be evaluated not only in the context of downslope mass movement or tectonic displacement. The role of external processes such as climate processes (trade winds, wave action and strength) and/or oceanic movements might play an important role in shaping these margins [Koenitz et al., 2008].

4.4 Seafloor unconformities and fluid flow indicators, Despite the identification of strong unconformity surfaces, the presence of fluid flow features at the seafloor marks the signature of the fluids migrating updip within the forearc structure. Fluids are acknowledged to play an important role in the evolution of collisional margins and their related basins [Moore and Vrolij, 1992]. Within the studied area we have identified sediment remobilization features, such as pockmarks [van Rensbergen et al., 2003]. These are spatially 
related to vertical discontinuities that are at the apex of faults of various types and in some areas with the occurrence of potential gas hydrates as marked by bottom-simulating reflectors (BSR) (Figures 5 and 6) [Auguy et al., 2017]. Shallow subsurface hydrological and hydrate systems within forearc basins offshore Peru have been identified [e.g., Kukowski and Pecher, 1999; von Huene and Pecher, 1999]. Unconformities in the Tumbes Basin associated with outcropping faulted structural highs are direct open conduits for fluid escape from the lower forearc and accreted structures in these margins. The role of the bottom currents in erosion/deposition as well as associated temperature variations has not yet been investigated. This could lead to a new evaluation of the buried hydrates systems and their past evolution.

4.5 Seafloor unconformities and paleoenvironment record, Our study underlines the importance of site location if a continuous or at least minimally reworked sequence is required for paleoenvironmental analysis. Further south, mud lenses located under the stress of the Peru-Chile Undercurrent (PCUC) [Salvatteci et al., 2014] show that laminae preservation at the regional scale is related to oxygen minimum zone intensity changes as well as variations in the strength of bottom currents. Erosion and winnowing of sediments by bottom currents could lead to uncertainties when computing absolute sedimentation rate [Krissek et al., 1980] and thus to budgets of biomass production and paleo-productivity estimates. Flushed sediments from onshore rivers caused by extreme runoff associated with strong El Niño events are dispersed over hundreds of kilometers along the shelf by the Peru Current and countercurrent [Scheidegger and Krissek, 1982; Rein et al., 2005]. De Vries and Percy [1982] studied fish debris and associated sediment along the margin and noted that these have been sorted during or after deposition. 


\section{Conclusions}

Based on the analysis of seafloor reflection and interpretation of our 3D seismic reflection data, we have mapped unconformities within the forearc basins of the Peru margin. From these results we infer the following conclusions:

-1: Mapping of 3D seismic intervals in the near-seafloor interval provides new insights to continental shelf and upper slope depositional processes and architectures. This could be extended to other provinces around the Pacific margins in subduction settings.

-2: The seismic geomorphology and reflection termination study of the seafloor shows important unconformity surfaces of various types over a wide range of water depths and latitudinal range. These have been framed within the present knowledge of the physical oceanography and are associated with bottom currents related to the Humboldt Peru-Chile Current as well as the wave dynamics of the eastern Pacific Ocean. These two movements of oceanic water mark important positive spatial and vertical correlations with the observed unconformity surfaces at the seafloor. -3: Typology of seafloor unconformity surfaces can be subdivided into structural or sedimentary origin with or without oceanic currents or wave action interaction. The role of the oceanic physical stress to the seafloor is of prime importance in shaping the margin and its evolution. -4: Many research topics from solid Earth, paleoenvironmental changes to biological sciences have yet failed to integrate these important unconformities and hiatuses as biases in their work. Care needs to be taken in future research when working in such settings.

\section{Acknowledgments}

This research project was conducted under the IRD-PERUPETRO S.A agreement. Seismic reflection data are archived at the PeruPetro Data Bank (http://www.perupetro.com.pe). Other sources are appropriately specified and cited. dGB Earth Sciences - OpendTect and IHS Kingdom are thanked for their Software University Grants, which have allowed this work to take 
place. Thanks to Alexis Chaigneau (IRD, LEGOS, Toulouse), Peter D. Clift (Louisiana State

Tables

\begin{tabular}{|c|c|c|c|c|c|c|c|c|c|}
\hline \multirow[t]{2}{*}{$\begin{array}{c}\text { Sedimentar } \\
\text { y basin }\end{array}$} & \multirow{2}{*}{$\begin{array}{l}\text { Dataset } \\
/ \\
\text { seismic } \\
\text { cube }\end{array}$} & \multirow[b]{2}{*}{$\begin{array}{l}\text { Latit } \\
\text { ude }\end{array}$} & \multicolumn{2}{|c|}{ Bathymetry } & \multirow{2}{*}{$\begin{array}{c}\begin{array}{c}\text { Survey } \\
\text { area }\end{array} \\
\mathrm{km}^{2}\end{array}$} & \multirow{2}{*}{$\begin{array}{c}\begin{array}{c}\text { Peak } \\
\text { freque } \\
\text { ncy }\end{array} \\
\\
\mathrm{Hz}\end{array}$} & \multirow{2}{*}{$\begin{array}{c}\text { Tuning } \\
\text { thickness - } \\
\text { vertical } \\
\text { resolution } \\
\mathrm{m}\end{array}$} & \multirow{2}{*}{$\begin{array}{c}\text { Slope } \\
\text { mean } \\
\text { (degree) }\end{array}$} & \multirow[t]{2}{*}{ Domain } \\
\hline & & & $\begin{array}{l}\min \\
(\mathrm{m})\end{array}$ & $\begin{array}{l}\max \\
(\mathrm{m})\end{array}$ & & & & & \\
\hline \multirow{2}{*}{ Tumbes } & $\mathrm{Z1}$ & $\begin{array}{l}3^{\circ} 45^{\prime} \\
\mathrm{S} \\
\end{array}$ & 24 & 411 & 1300 & 40 & 10 & 3,6 & $\begin{array}{l}\text { Shelf and } \\
\text { upper slope }\end{array}$ \\
\hline & Z38 & $\begin{array}{l}4^{\circ} 15^{\prime} \\
\mathrm{S} \\
\end{array}$ & 99 & 1380 & 1620 & 43 & 9 & 2,6 & $\begin{array}{l}\text { Shelf and } \\
\text { upper slope }\end{array}$ \\
\hline \multirow{2}{*}{ Talara } & Z34A & $\begin{array}{l}4^{\circ} 20^{\prime} \\
\mathrm{S} \\
\end{array}$ & 946 & 1895 & 194 & 47 & 8 & 5,95 & Upper slope \\
\hline & Z34E & $5^{\circ} \mathrm{S}$ & 196 & 2040 & 215 & 35 & 11 & 10 & $\begin{array}{l}\text { Shelf and } \\
\text { upper slope }\end{array}$ \\
\hline Salaverry & Z35 & $8^{\circ} \mathrm{S}$ & 112 & 202 & 880 & 35 & 11 & 1,75 & Shelf \\
\hline Pisco & Z33 & \begin{tabular}{|l|}
$12^{\circ} 3$ \\
$0^{\prime} \mathrm{S}$ \\
\end{tabular} & 108 & 323 & 663 & 32 & 12 & 1 & $\begin{array}{l}\text { Shelf and } \\
\text { upper slope }\end{array}$ \\
\hline
\end{tabular}

Table 1: Geographical and morphological properties of the seafloor for the four sedimentary

397 basins within the 3D seismic reflection data used for this study.

\begin{tabular}{|c|c|c|c|c|c|c|c|c|c|}
\hline \multirow{2}{*}{$\begin{array}{l}\text { Sedimentar } \\
\text { y basin }\end{array}$} & \multirow{2}{*}{$\begin{array}{l}\text { Datas } \\
\text { et / } \\
\text { seismi } \\
\text { c cube }\end{array}$} & \multicolumn{4}{|c|}{ Feature/shape } & \multicolumn{3}{|c|}{ Interpretation } & \multirow{2}{*}{$\begin{array}{l}\text { Unconformity \% } \\
\text { (minimum/mean/maximu } \\
\text { m) }\end{array}$} \\
\hline & & $\begin{array}{l}\text { linea } \\
\mathrm{r}\end{array}$ & $\begin{array}{l}\text { rounde } \\
\text { d }\end{array}$ & $\begin{array}{l}\text { mound } \\
\mathrm{s}\end{array}$ & $\begin{array}{l}\text { top } \\
\text { hig } \\
\text { h }\end{array}$ & $\begin{array}{l}\text { Structur } \\
\text { al }\end{array}$ & Sedimentary & $\begin{array}{l}\text { Fluid } \\
\text { flow }\end{array}$ & \\
\hline
\end{tabular}




\begin{tabular}{|c|c|c|c|c|c|c|c|c|c|}
\hline \multirow{2}{*}{ Tumbes } & $\mathrm{Z} 1$ & $\mathrm{x}$ & $x$ & $\mathrm{x}$ & & \begin{tabular}{|l} 
faults / \\
uplifted \\
structure \\
s
\end{tabular} & \begin{tabular}{|l} 
erosional \\
unconformitie \\
s, contourite \\
drift,
\end{tabular} & $\begin{array}{l}\text { pockmar } \\
\text { ks }\end{array}$ & \multirow{2}{*}{$26 / 44 / 68$} \\
\hline & Z38 & $\mathrm{x}$ & $x$ & $\mathrm{x}$ & $\mathrm{x}$ & \begin{tabular}{|l} 
faults / \\
uplifted \\
structure \\
s
\end{tabular} & $\begin{array}{l}\text { erosional } \\
\text { unconformitie } \\
\text { s, contourite } \\
\text { drift, moat }\end{array}$ & $\begin{array}{l}\text { pockmar } \\
\text { ks }\end{array}$ & \\
\hline \multirow[t]{2}{*}{ Talara } & Z34A & $\mathrm{x}$ & $\mathrm{x}$ & $\mathrm{x}$ & $\mathrm{x}$ & faults & $\begin{array}{l}\text { erosional } \\
\text { unconformitie } \\
\text { s, head scarp } \\
\text { of mass } \\
\text { wasting, } \\
\text { contourite } \\
\text { drift, channel, } \\
\text { lobe }\end{array}$ & $\begin{array}{l}\text { pockmar } \\
\text { ks }\end{array}$ & \multirow[t]{2}{*}{$18 / 36 / 53$} \\
\hline & Z34E & $\mathrm{x}$ & $\mathrm{x}$ & $\mathrm{x}$ & & fault & \begin{tabular}{|l} 
erosional \\
unconformitie \\
s, canyons, \\
contourite \\
drift \\
\end{tabular} & $\begin{array}{l}\text { not } \\
\text { identified }\end{array}$ & \\
\hline Salaverry & Z35 & $\mathrm{x}$ & $x$ & & $\mathrm{x}$ & fault & $\begin{array}{l}\text { erosional } \\
\text { unconformitie } \\
\text { s, prograding } \\
\text { canyon infill, } \\
\text { canyon edges }\end{array}$ & $\begin{array}{l}\text { not } \\
\text { identified }\end{array}$ & 100 \\
\hline Pisco & Z33 & $\mathrm{x}$ & & & $\mathrm{x}$ & $\begin{array}{l}\text { not } \\
\text { identifie } \\
\text { d }\end{array}$ & $\begin{array}{l}\text { erosional } \\
\text { unconformitie } \\
\text { s, channels, } \\
\text { wave cut } \\
\text { platform }\end{array}$ & $\begin{array}{l}\text { not } \\
\text { identified }\end{array}$ & 29 \\
\hline
\end{tabular}

Table 2: Morphological and seismic properties of the various features observed within the 3D seismic data volumes used for this study, and their interpretation.

Figures

Figure 1: Peru Continental Margin main forearc basins imaged with 3D seismic reflection data

403 and investigated (surveys: Z1, Z38, Z34A\&E, Z35). (a) Arrows indicate general flow directions

404 of surface currents (SEC: South Equatorial Current; EPCC: Ecuador-Peru Coastal Current; PCC:

405 Peru Coastal Current; POC: Peru Oceanic Current) and subsurface currents (EUC: Equatorial 
Undercurrent; pSSCC: primary (northern branch) Southern Subsurface Countercurrent; sSSCC: sSSCC: secondary (southern branch) Southern Subsurface Countercurrent; PCCC: Peru-Chile Countercurrent; CPDCC: Chile-Peru Deep Coastal Current; PCUC: Peru-Chile Undercurrent) [e.g., Chaigneau et al., 2013] along the Peru-Ecuador margin. (b) Offshore Peru wave rose diagram of an average year in terms of significant wave height (Hs) [Lopez et al., 2015].

Figure 2: Peruvian forearc basins and studied areas framed in the diagrams showing the features common to the two basic types of active margin: (a) accretionary and (b) erosive [adapted from Clift and Vannuchi, 2004]. Study areas and data set are located by the black rectangle above their respective type of active margin.

Figure 3: Bathymetric perspective views of the seafloor over the 3D seismic data used for this study in four different forearc basins offshore Peru (a. and b.: Tumbes; c. and d.: Talara; e.: Salaverry; f.: Pisco). The reader is referred to Table 1 for bathymetric ranges for each area.

Figure 4: Seafloor geomorphological (bathymetry: a) and seismic reflection properties (amplitude: b and semblance: c) within Tumbes Z1 area. Seismic cross section (d) uninterpreted and interpreted from Tumbes Z1 area. Concordant, toplap terminations and erosional truncations are associated with the seafloor seismic reflection. Faults and pockmarks are outcropping at the seafloor. An uplifted and eroded structure is outcropping in the northern part of the study area and is onlapped by recent reflection packages marked by a disconformity. The cross-hatch surfaces represent the labelled erosional truncation surfaces at the seafloor.

Figure 5: Seafloor geomorphological (bathymetry: a) and seismic reflection properties (amplitude: b and similarity: c) within Tumbes Z38 area. Seismic cross section (d) uninterpreted 
and interpreted from Tumbes Z38 area. Concordant, toplap terminations and erosional truncations are associated with the seafloor seismic reflection. Two sets of faults outcrop at the seafloor with orientation WNW-ESE and SW-NE respectively. Two types of mounded structures are observed, the first associated with a flat topped geometry and erosional truncations, and a second with smaller mounded elongated features related to contourite drifts. Pockmarks are observed to the SW of the study area, they are rooted from vertical discontinuities associated with gas chimneys. An uplifted erode structure is outcropping at the seafloor to the NE. The Banco Peru marks a prominent flat top structure that shoals in the NW part of the Tumbes Basin. The cross-hatch surfaces represent the labelled erosional truncation surfaces at the seafloor.

Figure 6: Seafloor geomorphological (bathymetry: a) and seismic reflection properties (amplitude: b and similarity: c) within Talara Z34A area. Seismic cross section (d) uninterpreted and interpreted from Talara Z34A area. Concordant, toplap terminations and erosional truncations are associated with the seafloor seismic reflection. Channels and lobes are sourced from the slope to pounded basins in the northern part of the study area. Between these, pockmarks are outcropping. These are associated to vertical discontinuities related to gas chimneys. Isolated mounds in the slope are associated with detached contourite drifts. Their edges are marked by erosional truncation. A negative seismic reflection crosscutting the surrounding seismic reflection corresponds to the “bottom-simulating reflection”, (BSR). This marks the occurrence of potential gas hydrates and free gas in the subsurface. The cross-hatch surfaces represent the labelled erosional truncation surfaces at the seafloor.

Figure 7: Seafloor geomorphological (bathymetry: a) and seismic reflection properties (amplitude: b and similarity: c) within Talara Z34E area. Seismic cross section (d) uninterpreted 
and interpreted from Talara Z34E area. Concordant, toplap terminations and erosional truncations are associated with the seafloor seismic reflection. Canyon walls are associated with toplap terminations and erosional truncations. The upper slope is composed of depositional features associated with contourite drift in the intercanyon area and erosional truncations updip. The shelf shows an important erosional truncation with outcropping faults of the overlying rotated faulted blocks. The cross-hatch surfaces represent the labelled erosional truncation surfaces at the seafloor.

Figure 8: Seafloor geomorphological (bathymetry: a) and seismic reflection properties (amplitude: b and similarity: c) within Salaverry Z35 area. Seismic cross section (d) uninterpreted and interpreted from Salaverry Z35 area. Toplap terminations and erosional truncations are associated with the seafloor seismic reflection. Various geometries are truncated, of which progradational sequences or canyons infills. The outcropping seismic sequences shows an older to younger stratigraphic age landward. The cross-hatch surfaces represent the labelled erosional truncation surfaces at the seafloor.

Figure 9: Seafloor geomorphological (bathymetry: a) and seismic reflection properties (amplitude: b and similarity: c) within Pisco Z33 area. Seismic cross section (d) uninterpreted and interpreted from Pisco Z33 area. Concordant, toplap terminations and erosional truncations are associated with the seafloor seismic reflection. An erosional truncation cuts a progradational sequence that is incised by linear to convergent seaward channel. The cross-hatch surfaces represent the labeled erosional truncation surfaces at the seafloor.

Figure 10: Synthesis of the depth of unconformities and oceanographic properties along the Peruvian margin. CTD station 7538849(C) and oceanographic data are from NOAA world ocean 
database WOD13. Water masses names are sourced from Chaigneau et al. [2013] (see Figure 1 and caption) and references within. Along shore integrated transport corresponds to the mean cross-shore section at $7^{\circ} \mathrm{S}-13^{\circ} \mathrm{S}$ between the coast and $200 \mathrm{~km}$ offshore.

Figure 11: Perspective view of the Peruvian margin and strength of erosion by oceanic processes (see Table 2). Arrows indicate general flow directions of surface currents (EPCC: Ecuador-Peru Coastal Current; PCC: Peru Coastal Current); and subsurface currents (EUC: Equatorial Undercurrent; pSSCC: primary (northern branch); CPDCC: Chile-Peru Deep Coastal Current; PCUC: Peru-Chile Undercurrent) [e.g., Chaigneau et al., 2013].

\section{References}

Arntz, W. E., J Tarazona, V Gallardo, L. A. Flores, and H Salzwedel (1991), Benthos communities in oxygen deficient shelf and upper slope areas of the Peruvian and Chilean Pacific coast, and changes caused by El Niño, Geological Society, London, Special Publications, 58, 131-154, doi:10.1144/GSL.SP.1991.058.01.10

Auguy, C., G. Calvès, Y. Calderon, and S. Brusset (2017), Seismic evidence of gas hydrates, multiple BSRs and fluid flow offshore Tumbes Basin - Peru, Marine Geophysical Research, 115, doi:10.1007/s11001-017-9319-2

Ballesteros, M.W., G.F. Moore, B. Taylor, and S. Ruppert (1988), Seismic stratigraphic framework of the Lima and Yaquina forearc basins, Peru. In: Suess, E., von Huene, R., et al., Proc. ODP, Init. Repts., 112: College Station, TX (Ocean Drilling Program), 77-90. doi:10.2973/odp.proc.ir.112.105.1988

Beaudry, D. and G. F. Moore (1981), Seismic-stratigraphic framework of the forearc basin off central Sumatra, Sunda Arc, Earth and Planetary Science Letters, 54(1), 17-28, doi:10.1016/0012-821X(81)90065-0.

Bernhardt, A., D. Melnick, J. Jara-Muñoz, B. Argandoña, J. González, and M. R. Strecker (2015), Controls on submarine canyon activity during sea-level highstands: The Biobío canyon system offshore Chile, Geosphere, 11 (4), 1226-1255, doi: 10.1130/GES01063.1

Bernhardt, A., D. Hebbeln, M. Regenberg, A. Lückge, and M. R. Strecker (2016), Shelfal sediment transport by an undercurrent forces turbidity-current activity during high sea level along the Chile continental margin, Geology, 44, 295-298, doi:10.1130/G37594.1 
Blackwelder, E. (1909), The Valuation of Unconformities, The Journal of Geology, 17(3), 289299, Retrieved from http://www.jstor.org/stable/30068167

Bourgois, J., G. Pautot, W. Bandy, T. Boinet, P. Chotin, P. Huchon, B. Mercier de Lepinay, F. Monge, J. Monlau, B. Pelletier, M. Sosson, and R. von Huene (1988), Seabeam and seismic reflection imaging of the tectonic regime of the Andean continental margin off Peru $\left(4^{\circ} \mathrm{S}\right.$ to $10^{\circ}$ S), Earth and Planetary Science Letters, 87(1-2), 111-126, doi:10.1016/0012821X(88)90068-4

Boyer, T.P., J. I. Antonov, O. K. Baranova, C. Coleman, H. E. Garcia, A. Grodsky, D. R. Johnson, R. A. Locarnini, A. V. Mishonov, T.D. O'Brien, C.R. Paver, J.R. Reagan, D. Seidov, I. V. Smolyar, and M. M. Zweng (2013), World Ocean Database 2013, NOAA Atlas NESDIS 72, S. Levitus, Ed., A. Mishonov, Technical Ed.; Silver Spring, MD, 209 pp., doi: 10.7289/V5NZ85MT

Brockmann, C., E. Fahrbach, A. Huyer, and R.L. Smith (1980), The poleward undercurrent along the Peru coast: 5 to $15^{\circ} \mathrm{S}$, Deep Sea Research Part A. Oceanographic Research Papers, 27(10), 847-856, doi:10.1016/0198-0149(80)90048-5.

Bulat J. (2005), Some considerations on the interpretation of seabed images based on commercial 3D seismic in the Faroe-Shetland Channel, Basin Research, 17, 21-42, doi:10.1111/j.1365-2117.2005.00253.x

Cartwright J. and M. Huuse (2005), 3D seismic technology: the geological 'Hubble', Basin Research, 17(1), 1-20, doi: 10.1111/j.1365-2117.2005.00252.x

Chaigneau, A., N. Dominguez, G. Eldin, L. Vasquez, R. Flores, C. Grados, and V. Echevin (2013), Near-coastal circulation in the Northern Humboldt Current System from shipboard ADCP data, J. Geophys. Res. Oceans, 118, 5251-5266, doi:10.1002/jgrc.20328.

Clift, P.D., and A.J. Hartley (2007), Slow rates of subduction erosion along the Andean margin and reduced global crustal recycling, Geology, 35(6), 503-506, doi: 10.1130/G23584A.1

Clift, P. D., I. Pecher, N. Kukowski, and A. Hampel (2003), Tectonic erosion of the Peruvian forearc, Lima Basin, by subduction and Nazca Ridge collision, Tectonics, 22, 1023, doi:10.1029/2002TC001386, 3.

Clift, P., and P. Vannucchi (2004), Controls on tectonic accretion versus erosion in subduction zones: Implications for the origin and recycling of the continental crust, Reviews of Geophysics, v. 42, p. RG2001, doi:10.1029/2003RG000127

Collier, J. S., S. Gupta, G. Potter, and A. Palmer-Felgate (2006), Using bathymetry to identify basin inversion structures on the English Channel shelf, Geology, 34(12), 1001-1004, doi:10.1130/G22714A.1 
Cotton, C. (1918), Conditions of deposition on the continental shelf and slope, The Journal of Geology, 26(2), 135-160. Retrieved from http://www.jstor.org/stable/30080728

De Vries, T. J., and W. G. Pearcy (1982), Fish debris in sediments of the upwelling zone off central Peru: a late Quaternary record, Deep Sea Research Part A. Oceanographic Research Papers, 29(1), 87-109, doi:10.1016/0198-0149(82)90063-2.

Dickinson, W.R. (1995), Forearc basins. In: Tectonics of Sedimentary basins (Ed. by C.J. Busby and R.V. Ingersoll) p. 221-261, Blackwell Scientific Publications, Oxford

Echevin, V., O. Aumont, J. Ledesma, and G. Flores (2008), The seasonal cycle of surface chlorophyll in the Peruvian upwelling system: A modelling study, Progress in Oceanography, 79 (2-4), 167-176, doi:10.1016/j.pocean.2008.10.026.

Erdem, Z., J. Schönfeld, N. Glock, M. Dengler, T. Mosch, S. Sommer, J. Elger, and A. Eisenhauer (2016), Peruvian sediments as recorders of an evolving hiatus for the last 22 thousand years, Quaternary Science Reviews, 137, 1-14, doi: 10.1016/j.quascirev.2016.01.029.

Frederik, M. C. G., S. P. S. Gulick, J. A. Austin Jr., N. L. B. Bangs, and Udrekh (2015), What 2D multichannel seismic and multibeam bathymetric data tell us about the North Sumatra wedge structure and coseismic response, Tectonics, 34, 1910-1926, doi:10.1002/2014TC003614.

Gallardo, VA (1977), Large benthic microbial communities in sulphide biota under Peru-Chile subsurface countercurrent, Nature, 268, 331-332. doi:10.1038/268331a0s

Grant, J. A., and R. Schreiber (1990), Modern swathe sounding and sub-bottom profiling technology for research applications: The Atlas Hydrosweep and Parasound Systems, Marine Geophysical Researches, 12(1), 9-19, doi:10.1007/978-94-009-0615-0_2

Gulick, S.P.S., N.L.B. Bangs, G.F. Moore, J. Ashi, K.M. Martin, D.S. Sawyer, H.J. Tobin, S. Kuramoto, and A. Taira (2010), Rapid forearc basin uplift and megasplay fault development from 3D seismic images of Nankai Margin off Kii Peninsula, Japan, Earth and Planetary Science Letters, 300(1-2), 55-62, doi:10.1016/j.epsl.2010.09.034.

Gupta, S., J. S. Collier, A. Palmer-Felgate and G. Potter (2007), Catastrophic flooding origin of shelf valley systems in the English Channel, Nature, 448, 342-345. doi:10.1038/nature06018

Hagen, R.A., D. D. Bergersen, R. Moberly, and W. T. Coulbourn (1994), Morphology of a large meandering submarine canyon system on the Peru-Chile forearc, Marine Geology, 119(1), 7-38, doi:10.1016/0025-3227(94)90138-4.

Hay W.W. (2015), Erosion Hiatuses, Encyclopedia of Marine Geosciences, 1-5, doi: 10.1007/978-94-007-6644-0_57-5 
Hebbeln D., M. Marchant, T. Freudenthal, and G. Wefer (2000), Surface sediment distribution along the Chilean continental slope related to upwelling and productivity, Marine Geology, 164(3-4), 119-137, doi:10.1016/S0025-3227(99)00129-2.

Huuse, J. (2011), 3D seismic characterization of the Norwegian Channel Ice Stream: Spatiotemporal evolution of a major cross-shelf trough through multiple glaciations, Quaternary International, Volumes 279-280, 213, doi:10.1016/j.quaint.2012.08.420.

Jara-Muñoz, J., D. Melnick, P. Zambrano, A. Rietbrock, J. González, B. Argandoña and M. R. Strecker (2017), Quantifying offshore fore-arc deformation and splay-fault slip using drowned Pleistocene shorelines, Arauco Bay, Chile, J. Geophys. Res. Solid Earth, 122, doi:10.1002/2016JB013339.

Koenitz, D., N. White, I. N. McCave, and R. Hobbs (2008), Internal structure of a contourite drift generated by the Antarctic Circumpolar Current, Geochem. Geophys. Geosyst., 9, Q06012, doi:10.1029/2007GC001799.

Krissek, L. A., K. F. Scheidegger, and L. D. Kulm (1980), Surface sediments of the Peru-Chile continental margin and the Nazca plate, GSA Bulletin, 91(6), 321-331; doi:10.1130/00167606(1980) $91<321:$ SSOTPC>2.0.CO;2

Kulm, L. D., T. M. Thornburg, H. J. Schraderand, and J. M. Resig (1982), Cenozoic structure, stratigraphy and tectonics of the central Peru forearc, Geological Society, London, Special Publications, 10(1), 151-169, doi:10.1144/GSL.SP.1982.010.01.10

Kulm, L. D., H. Schrader, J. M. Resig, T. M. Thornburg, A. Masias, and L. Johnson (1981), Late Cenozoic carbonates on the Peru continental margin: Lithostratigraphy, biostratigraphy, and tectonic history, Geological Society of America Memoirs, 154, 469-508, doi:10.1130/MEM154p469

Kukowski, N., and I. Pecher (1999), Thermo-hydraulics of the Peruvian accretionarycomplex at $12^{\circ}$ S, Journal of Geodynamics, 27(3), 373-402, doi:10.1016/S0264-3707(98)00009-X.

Lamb H. (1994), Hydrodynamics: Cambridge, UK, Cambridge University Press, 768 p.

López, M., M. Veigas, and G. Iglesias (2015), On the wave energy resource of Peru, Energy Conversion and Management, 90, 34-40, doi:10.1016/j.enconman.2014.11.012

McCave I. N. (1984), Erosion, transport and deposition of fine-grained marine sediments, Geological Society, London, Special Publications, 15, 35-69, doi:10.1144/GSL.SP.1984.015.01.03

McNeill, L. C., and T. J. Henstock (2014), Forearc structure and morphology along the SumatraAndaman subduction zone, Tectonics, 33, 112-134, doi:10.1002/2012TC003264. 
Miall, Andrew D. (2016), The valuation of unconformities, Earth-Science Reviews, 163, 22-71, doi:10.1016/j.earscirev.2016.09.011

Mitchell, N. C., J. M. Huthnance, T. Schmitt and B. Todd (2013), Threshold of erosion of submarine bedrock landscapes by tidal currents, Earth Surface Processes and Landforms, 38(6), 627-639, doi:10.1002/esp.3347

Mitchum, R. M., P. R. Vail, and J. B. Sangree (1977), Stratigraphic interpretation of seismic reflection patterns in depositional sequences. part 6, in Seismic Stratigraphy-Application to Hydrocarbon Exploration, 8th ed., edited by C. E. Payton, pp. 117-133, AAPG, Tulsa, Okla.

Moberly, R., G. L. Shepherd, and W. T. Coulbourn (1982), Forearc and other basins, continental margin of northern and southern Peru and adjacent Ecuador and Chile, Geological Society, London, Special Publications, 10(1), 171-189, doi:10.1144/GSL.SP.1982.010.01.11

Moore, G. F., and B. Taylor (1988), Structure of the Peru forearc from multichannel seismic reflection data, Proc. Ocean Drill. Program Initial Rep., 112, 71-76.

Moore, J. C., and P. Vrolijk (1992), Fluids in accretionary prisms, Rev. Geophys., 30(2), 113135, doi:10.1029/92RG00201.

Muñoz, P., C.B. Lange, D. Gutiérrez, D. Hebbeln, M.A. Salamanca, L. Dezileau, J.L. Reyss, and L.K. Benninger (2004), Recent sedimentation and mass accumulation rates based on $210 \mathrm{~Pb}$ along the Peru-Chile continental margin, Deep Sea Research Part II: Topical Studies in Oceanography, 51(20-21), 2523-2541, doi:10.1016/j.dsr2.2004.08.015.

Noda A. (2016), Forearc basins: Types, geometries, and relationships to subduction zone dynamics, GSA Bulletin, 128(5-6), 879-895; doi:10.1130/B31345.1.

Pietri, A., V. Echevin, P. Testor, A. Chaigneau, L. Mortier, C. Grados, and A. Albert (2014), Impact of a coastal-trapped wave on the near-coastal circulation of the Peru upwelling system from glider data, J. Geophys. Res. Oceans, 119, 2109-2120, doi:10.1002/2013JC009270.

Posamentier, H. W., R. J. Davies, J. A. Cartwright, and L. Wood (2007). Seismic geomorphology-an overview, Geological Society, London, Special Publications, 277(1), 1-14. doi:10.1144/GSL.SP.2007.277.01.01

Ramsey, L. A., N. Hovius, D. Lague, and C.-S. Liu (2006), Topographic characteristics of the submarine Taiwan orogen, J. Geophys. Res., 111, F02009, doi:10.1029/2005JF000314.

Reading H.G., and J.D. Collinson (1996), Clastic coasts, in Reading H.G., ed., Sedimentary environments: Processes, facies and stratigraphy: Oxford, UK, Blackwell Science, pp. 154-258.

Reimers, C.E., and E. Suess (1983), Spatial and temporal patterns of organic matter accumulation on the Peru continental margin, in: coastal Upwelling and its sedimentary record 
part B: Sedimentary Records of Ancient Coastal Upwelling. In: Thiede, J., Suess, E. (Eds.), NATO Conference Series IV: Mar. Sci., vol. 10b, pp. 311-346.

Rein, B., A. Lückge, L. Reinhardt, F. Sirocko, A. Wolf, and W.-C. Dullo (2005), El Niño variability off Peru during the last 20,000 years, Paleoceanography, 20, PA4003, doi:10.1029/2004PA001099.

Reinhardt, L., H.-R. Kudrass, A. Lückge, M. Wiedicke, J. Wunderlich, and G. Wendt (2002), High-resolution sediment echosounding off Peru: Late Quaternary depositional sequences and sedimentary structures of a current-dominated shelf, Marine Geophysical Researches, 23(4), 335-351, doi:10.1023/A:1025781631558

Saillard, M., S.R. Hall, L. Audin, D.L. Farber, G. Hérail, J. Martinod, V. Regard, R.C. Finkel, and F. Bondoux (2009), Non-steady long-term uplift rates and Pleistocene marine terrace development along the Andean margin of Chile (31 $\left.{ }^{\circ} \mathrm{S}\right)$ inferred from $10 \mathrm{Be}$ dating, Earth and Planetary Science Letters, 277(1-2), 50-63, doi: 10.1016/j.epsl.2008.09.039

Salvatteci, R., D. Field, A. Sifeddine, L. Ortlieb, V. Ferreira, T. Baumgartner, S. Caquineau, F. Velazco, J.-L.s Reyss, J.-A. Sanchez-Cabeza, and D. Gutierrez (2014), Cross-stratigraphies from a seismically active mud lens off Peru indicate horizontal extensions of laminae, missing sequences, and a need for multiple cores for high resolution records, Marine Geology, 357(1), 72-89, doi:10.1016/j.margeo.2014.07.008.

Scheidegger, K. F., and L. A. Krissek (1982), Dispersal and deposition of eolian and fluvial sediments off Peru and northern Chile, GSA Bulletin, 93 (2) 150-162, doi:10.1130/00167606(1982)93<150:DADOEA>2.0.CO;2

Scholl, D. W., R. von Huene, T. L. Vallier, and D. G. Howell (1980), Sedimentary masses and concepts about tectonic processes at underthrust ocean margins, Geology, 8 (12) 564-568; doi: 10.1130/0091-7613(1980)8<564:SMACAT>2.0.CO;2

Shepard F. P. and U. S. Grant IV (1947), Wave erosion along the southern California Coast, Geological Society of America Bulletin, 58(10), 919-926, doi:10.1130/00167606(1947)58[919:WEATSC]2.0.CO;2

Shipboard Scientific Party, (1988), Introduction, objectives, and principal results, Leg 112, Peru continental margin, In: Suess, E., von Huene, R., et al., Proc. ODP, Init. Repts., 112: College Station, TX (Ocean Drilling Program), 5-23. doi:10.2973/odp.proc.ir.112.102.1988

Sosson, M., J. Bourgois, and B. Mercier de Lépinay (1994), SeaBeam and deep-sea submersible Nautile surveys in the Chiclayo canyon off Peru $\left(7^{\circ} \mathrm{S}\right)$ : Subsidence and subduction-erosion of an Andean-type convergent margin since Pliocene times, Marine Geology, 118(3-4), 237-256, doi:10.1016/0025-3227(94)90086-8

Steffens, G. S., R. C. Shipp, B. E. Prather, J. A. Nott, J. L. Gibson and C. D. Winker (2004), The use of near-seafloor 3D seismic data in deepwater exploration and production (in 3D seismic 
technology; application to the exploration of sedimentary basins, R. J. Davies, et al.), Memoirs of the Geological Society of London, 29, 35-43, doi: 10.1144/GSL.MEM.2004.029.01.04.

Stern, C. R. (2011), Subduction erosion: Rates, mechanisms, and its role in arc magmatism and the evolution of the continental crust and mantle, Gondwana Research, 20(2-3), 284-308, doi:10.1016/j.gr.2011.03.006.

Suess, E. (1980), Particulate organic carbon flux in the oceans-surface productivity and oxygen utilization, Nature, 288, 260-263, doi:10.1038/288260a0

Thornburg, T., and L. D. Kulm (1981), Sedimentary basins of the Peru continental margin: Structure, stratigraphy, and Cenozoic tectonics from $6^{\circ} \mathrm{S}$ to $16^{\circ} \mathrm{S}$ latitude, Geological Society of America Memoirs, 154, 393-422, doi:10.1130/MEM154-p393

Tsuchiya, M., and L. D. Talley (1998), A Pacific hydrographic section at $88^{\circ} \mathrm{W}$ : Water-property distribution, J. Geophys. Res., 103(C6), 12899-12918, doi:10.1029/97JC03415.

Vail, P. R., R. M. Mitchum, and S. Thompson (1977), Seismic stratigraphy and global changes of sea-level. part 3: Relative changes of sea level from coastal onlap, in Seismic StratigraphyApplications to Hydrocarbon Exploration, AAPG Mem., vol. 26, edited by C. E. Payton, pp. 6381, AAPG, Tulsa, Okla.

Vail, P. R., R. M. Mitchum, T. H. Shipley, R. T. Buffler, and D. H. Matthews (1980), Unconformities of the North Atlantic [and Discussion], Phil. Trans. R. Soc. Lond. A, 294, 137155, doi:10.1098/rsta.1980.0021.

Van Rensbergen, P., R. R. Hillis, A. J. Maltman, and C. K. Morley (2003), Subsurface sediment mobilization: introduction, Geological Society, London, Special Publications, 216, 1-8, doi:10.1144/GSL.SP.2003.216.01.01.

Vannucchi, P., J. P. Morgan, E. A. Silver, and J. W. Kluesner (2016), Origin and dynamics of depositionary subduction margins, Geochem. Geophys. Geosyst., 17, 1966-1974, doi:10.1002/2016GC006259.

von Huene, R., and. S Lallemand (1990), Tectonic erosion along the Japan and Peru convergent margins, Geological Society of America Bulletin, 102( 6), 704-720, doi:10.1130/00167606(1990)102<0704:TEATJA>2.3.CO;2

von Huene, R., and I. A Pecher (1999), Vertical tectonics and the origins of BSRs along the Peru margin, Earth and Planetary Science Letters, 166(1-2), 47-55, doi:10.1016/S0012821X(98)00274-X.

Witt C. and J. Bourgois (2010), Forearc basin formation in the tectonic wake of a collisiondriven, coastwise migrating crustal block: The example of the North Andean block and the extensional Gulf of Guayaquil-Tumbes Basin (Ecuador-Peru border area), Geological Society of America Bulletin, 122(1-2), 89-108, doi: 10.1130/B26386.1 


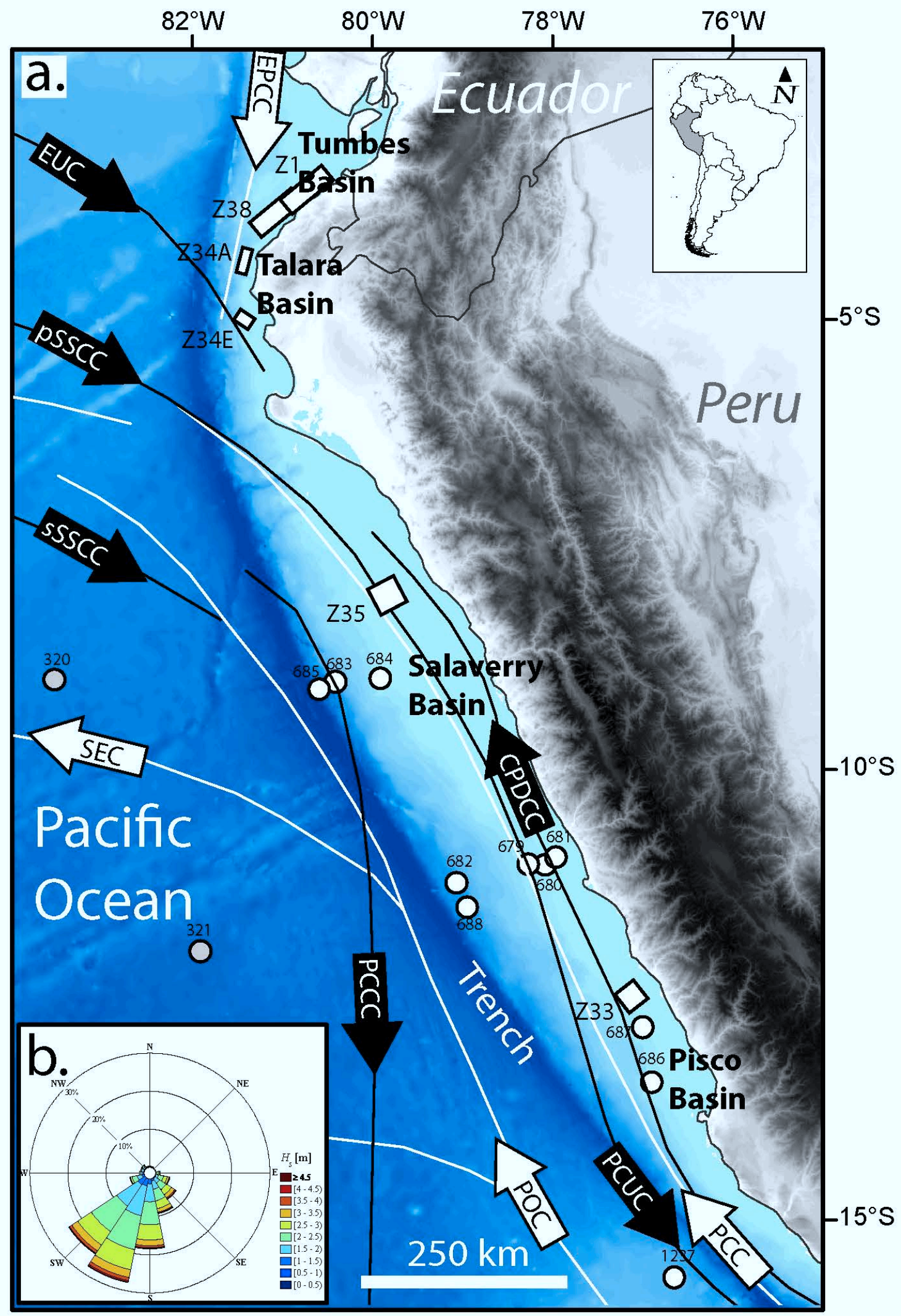


a.

\section{Pisco - Z33 Tumbes - Z1\&38}

Arc volcanlc front

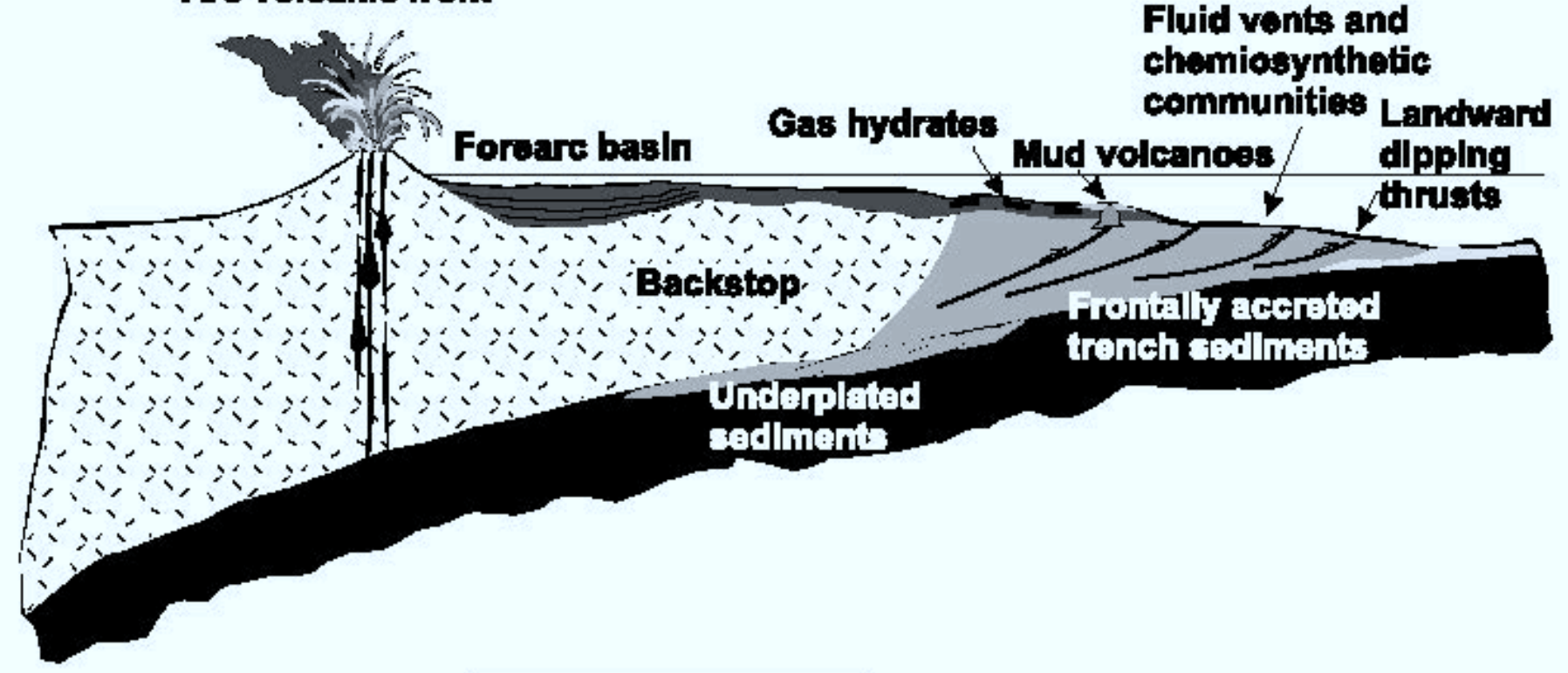

b.

\section{Salaverry- Z35}

Arc voleanic front

\section{Talara - Z34A\&E}

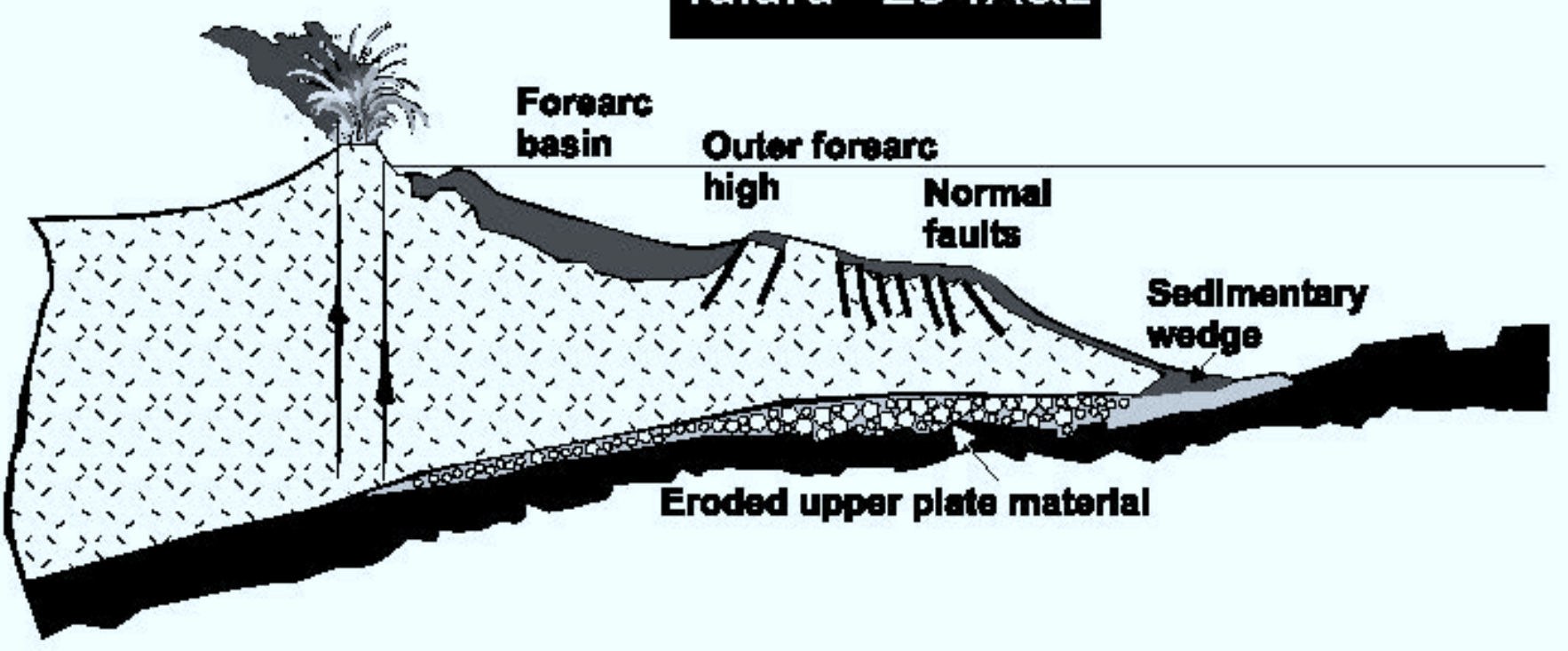



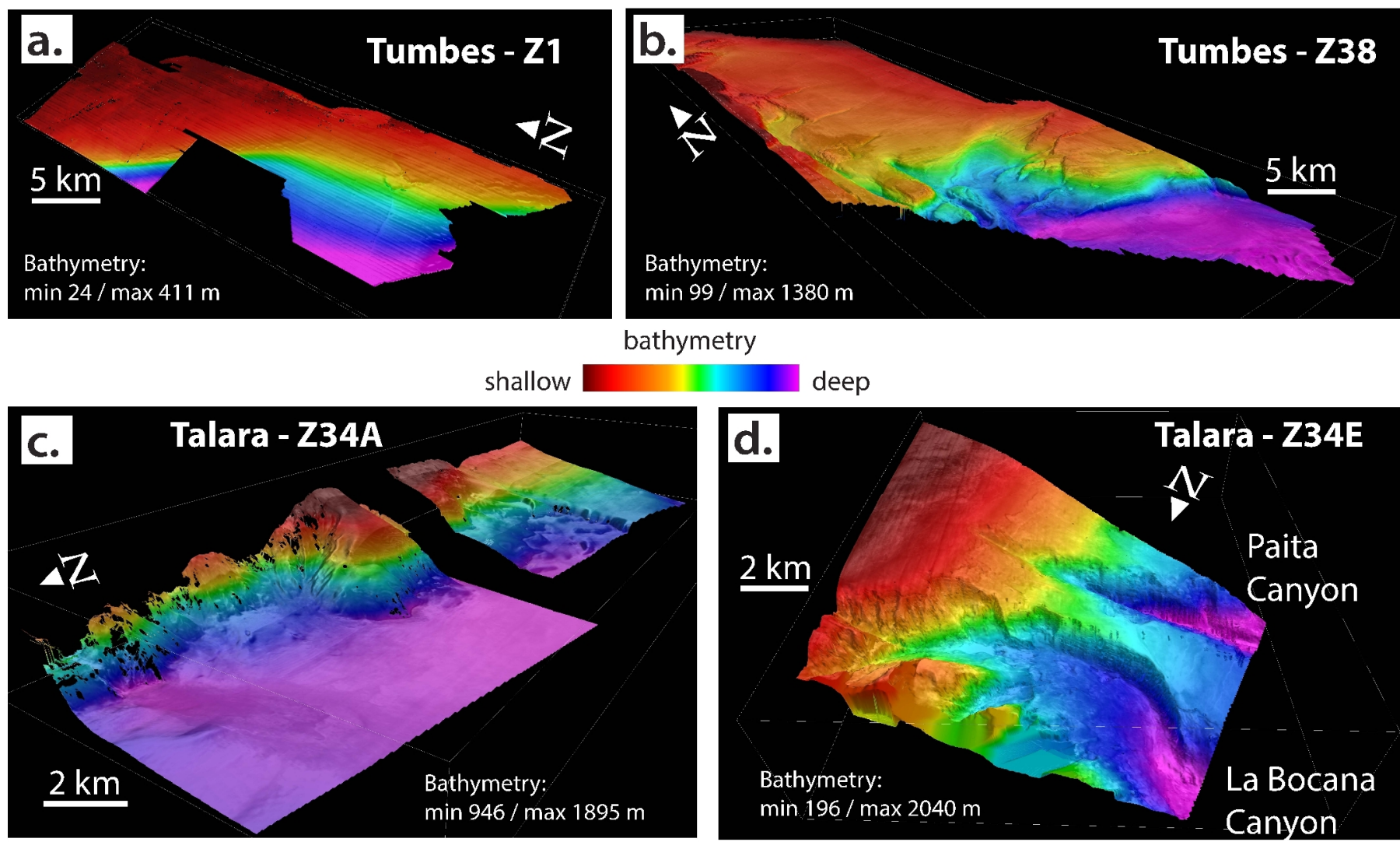

$\min 99$ / $\max 1380$ m

metry
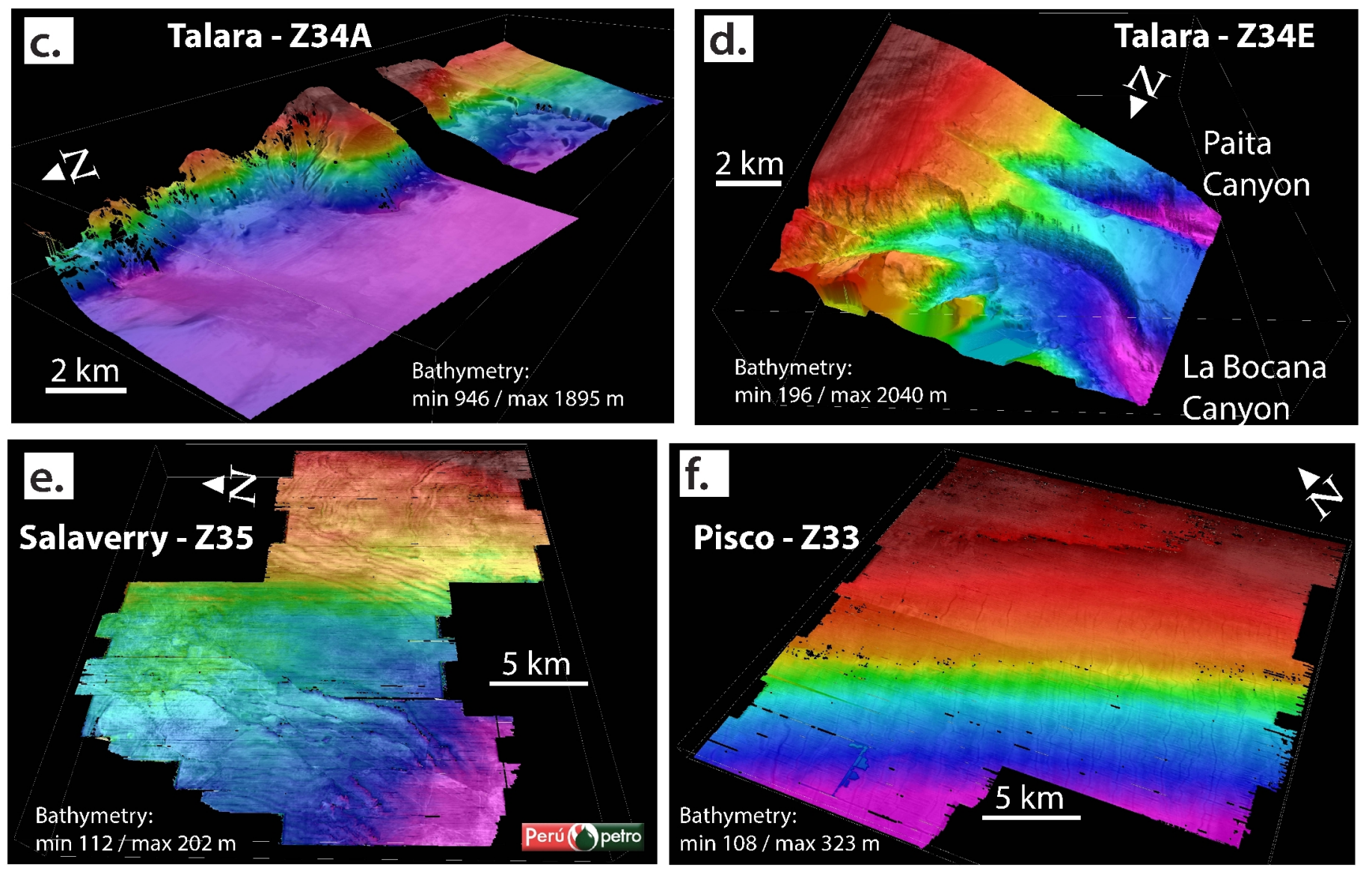

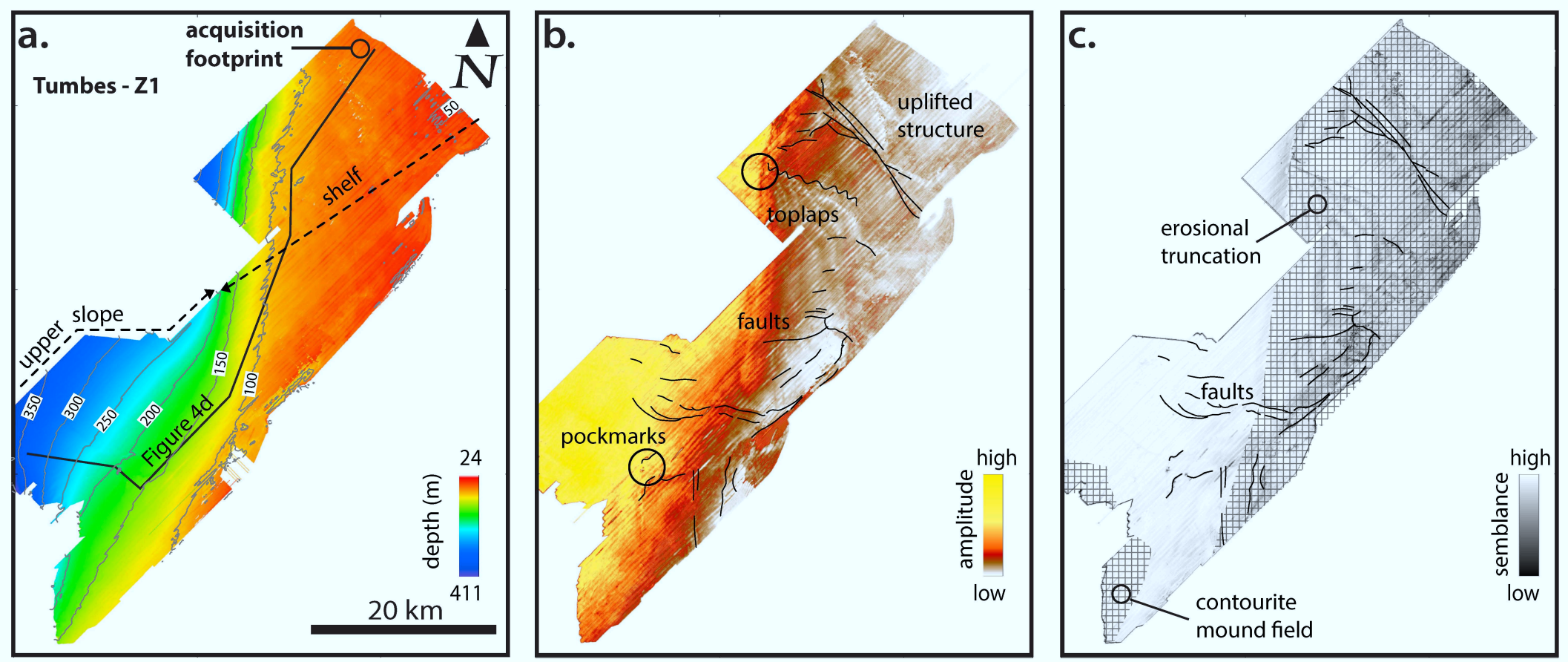

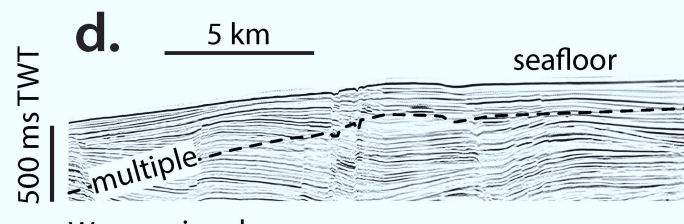

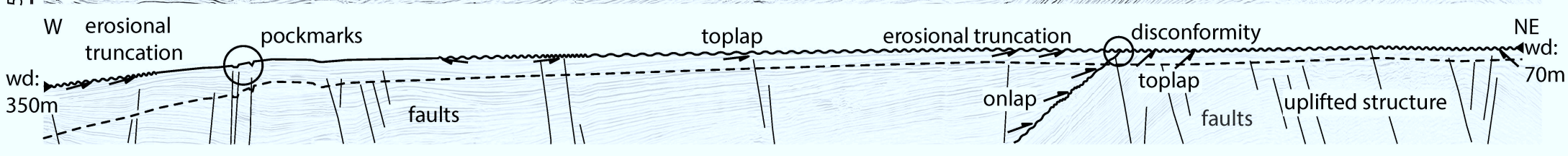




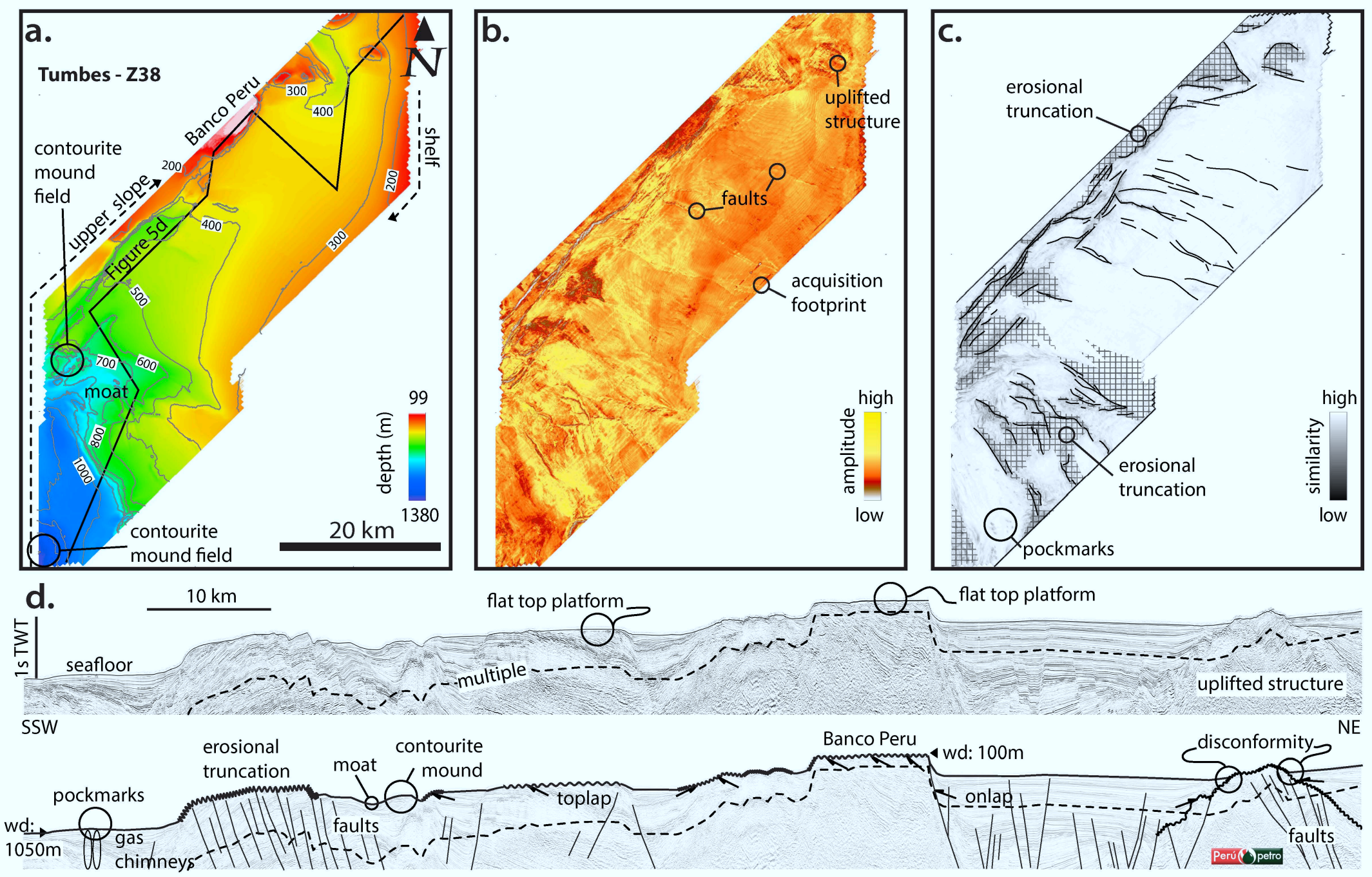



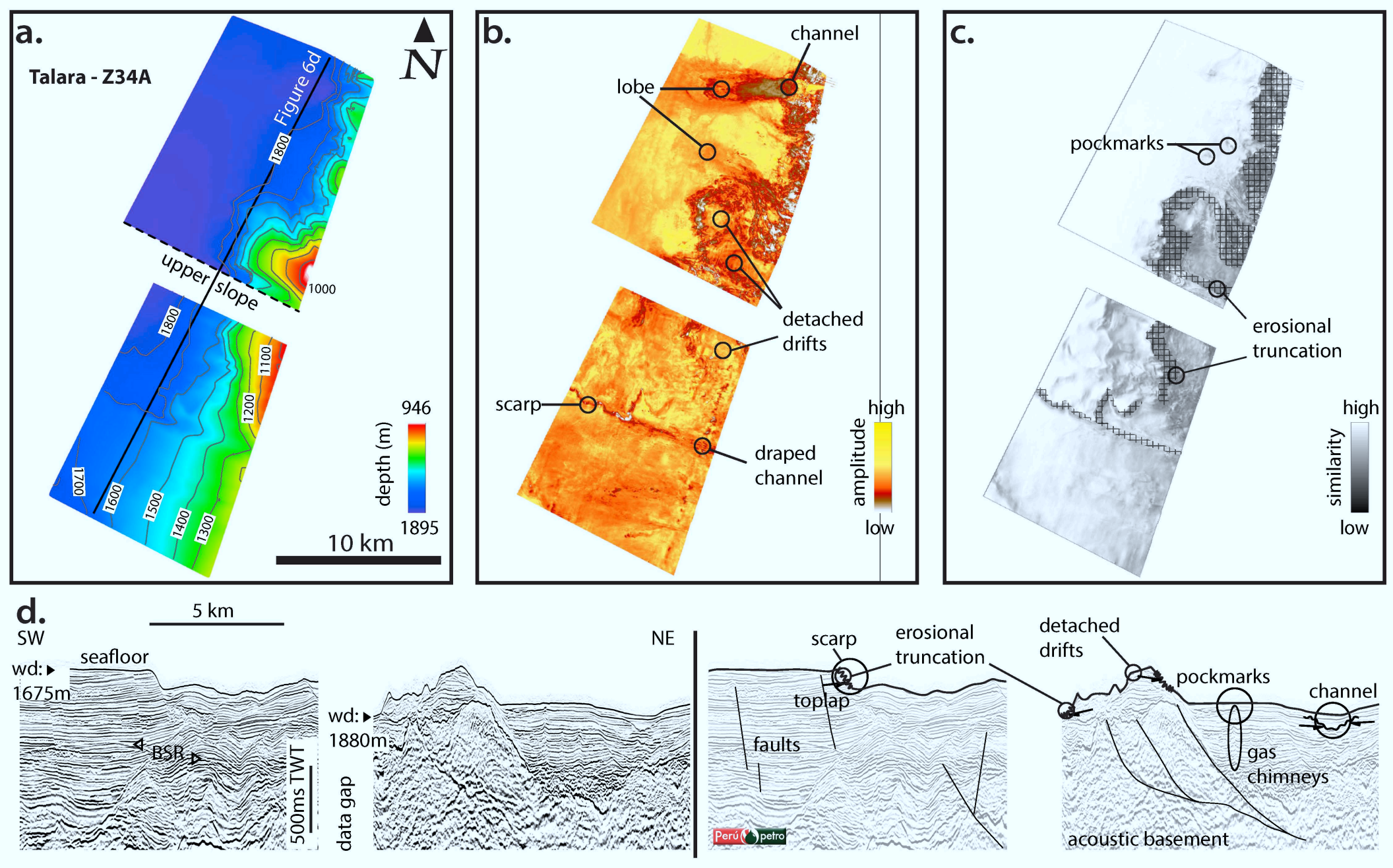

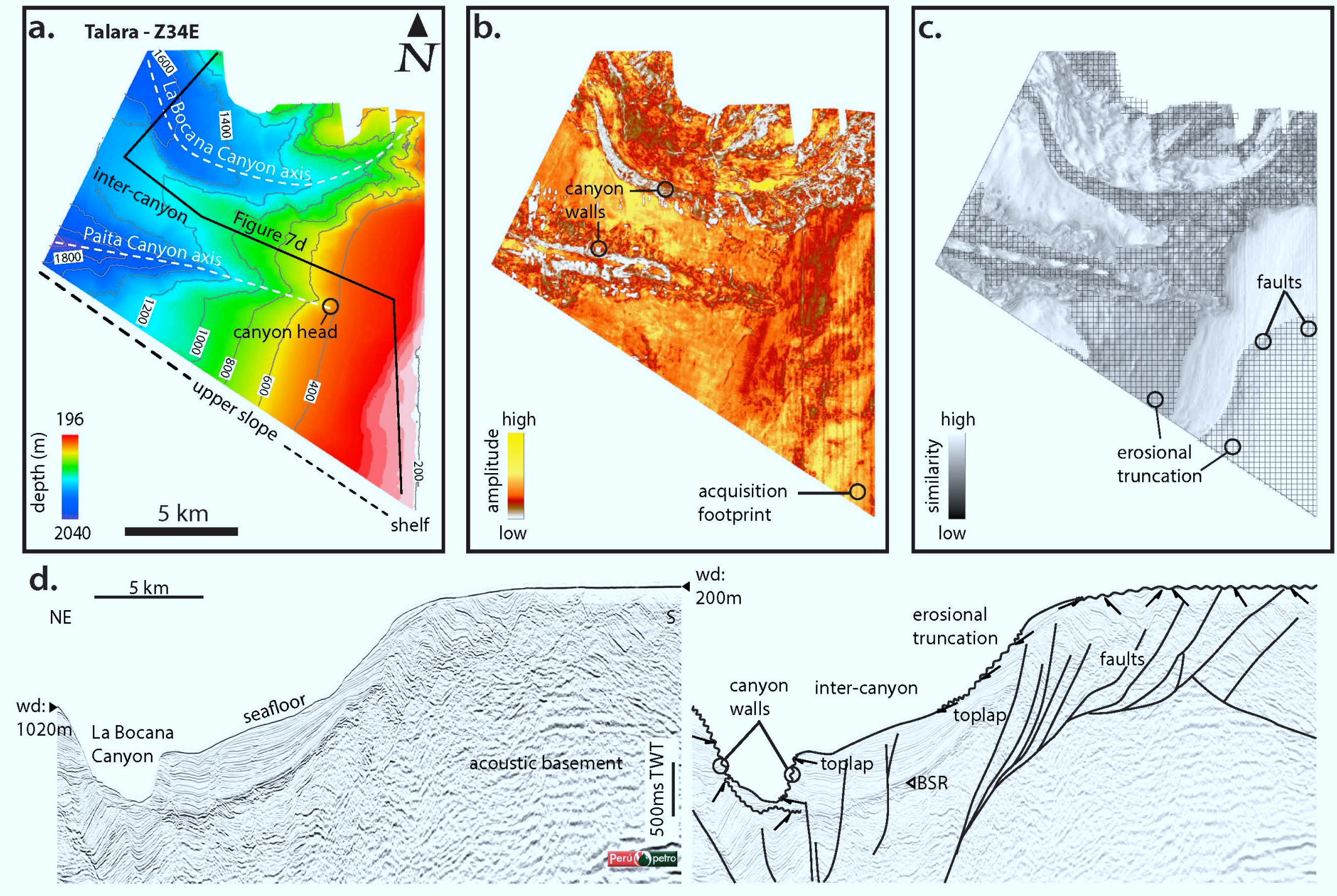

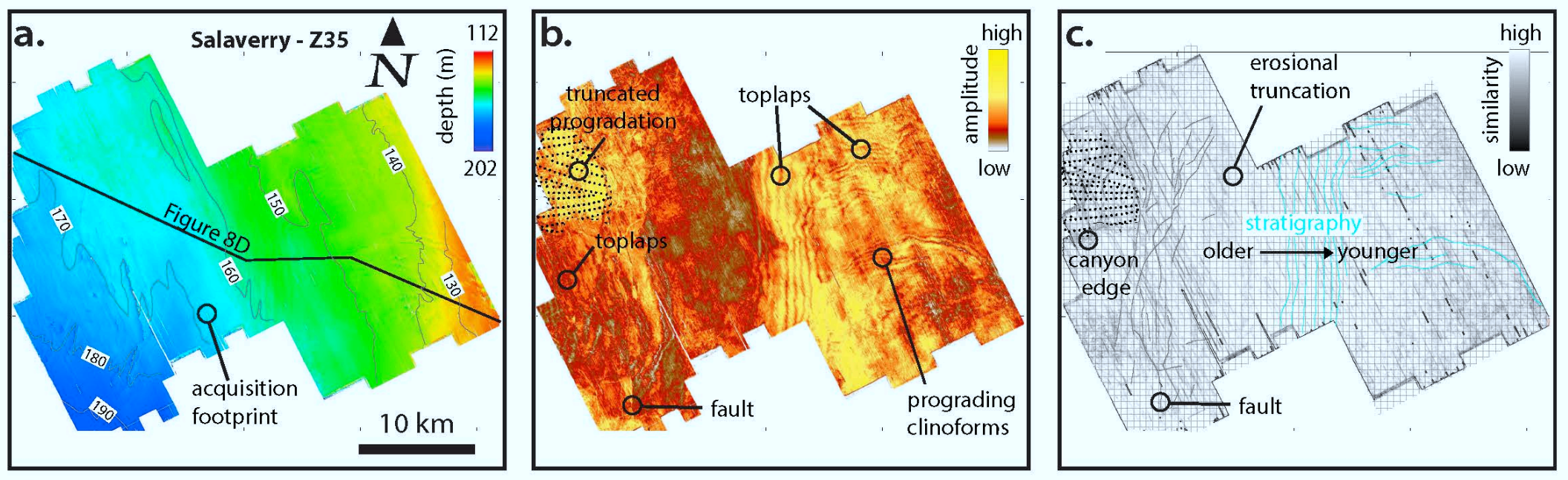

\section{d. $\mathrm{NW}$}

wd: ____ seafloor

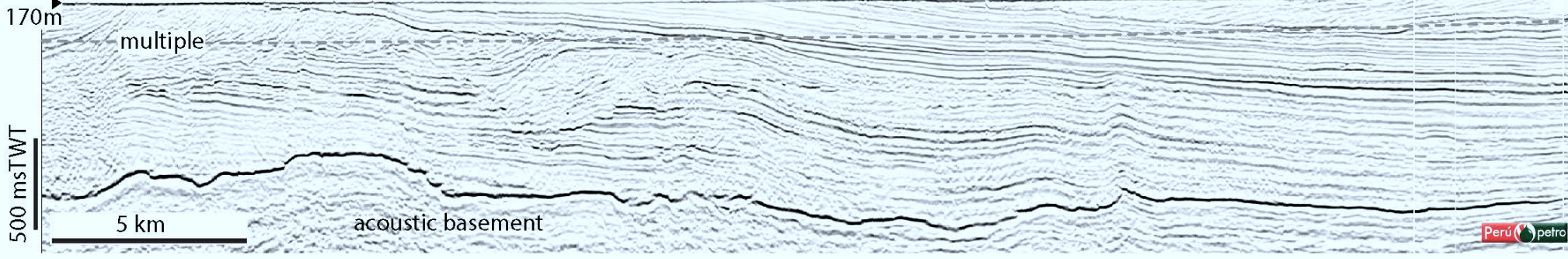
toplap

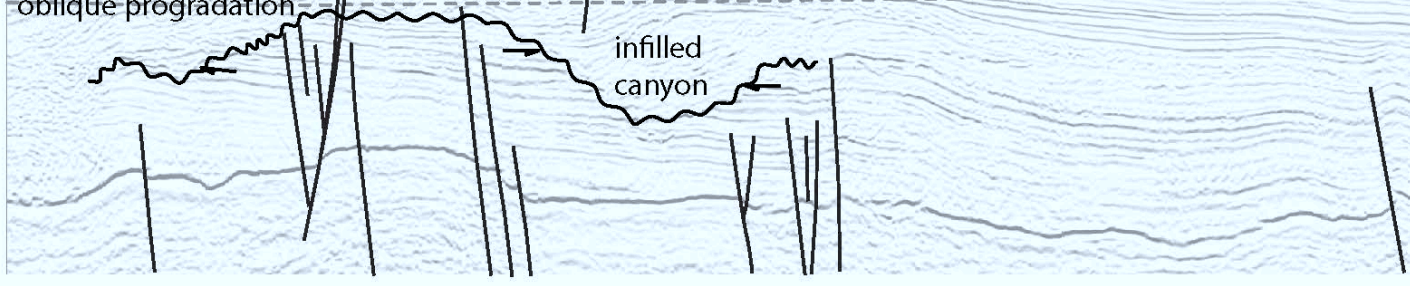



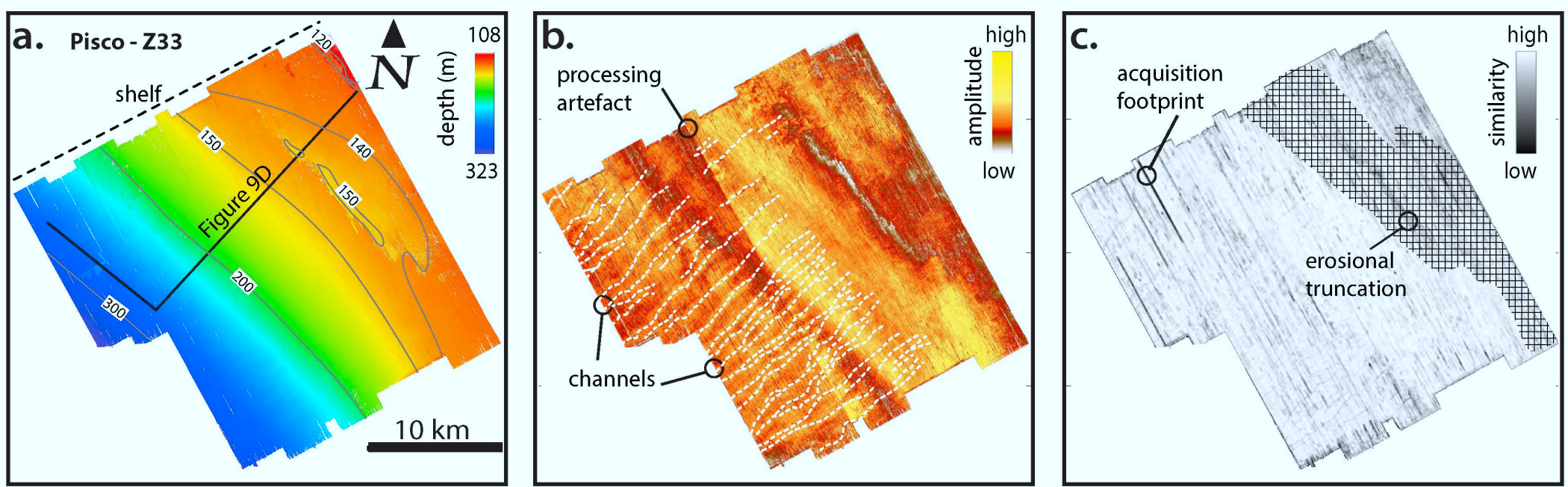

d.

NW

seafloor

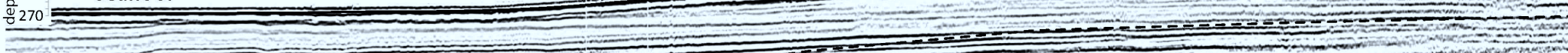

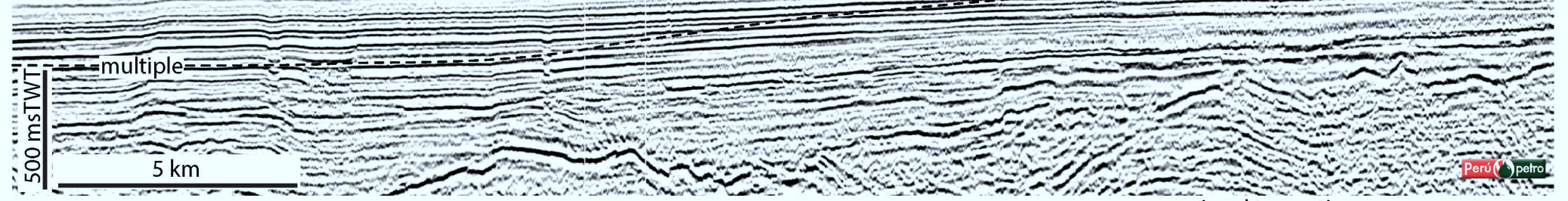

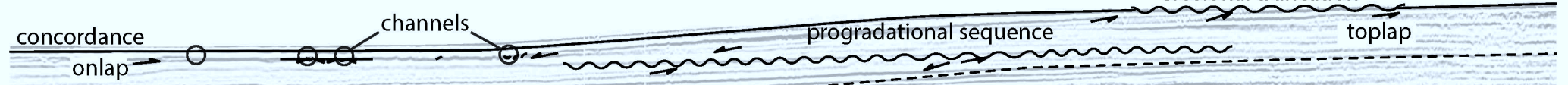

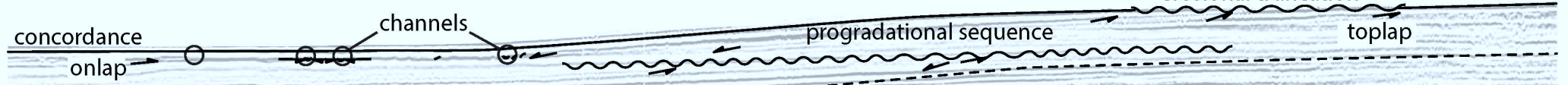
erosional truncation

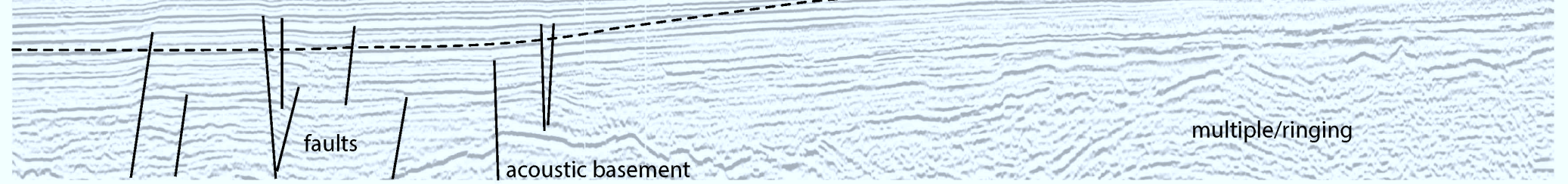




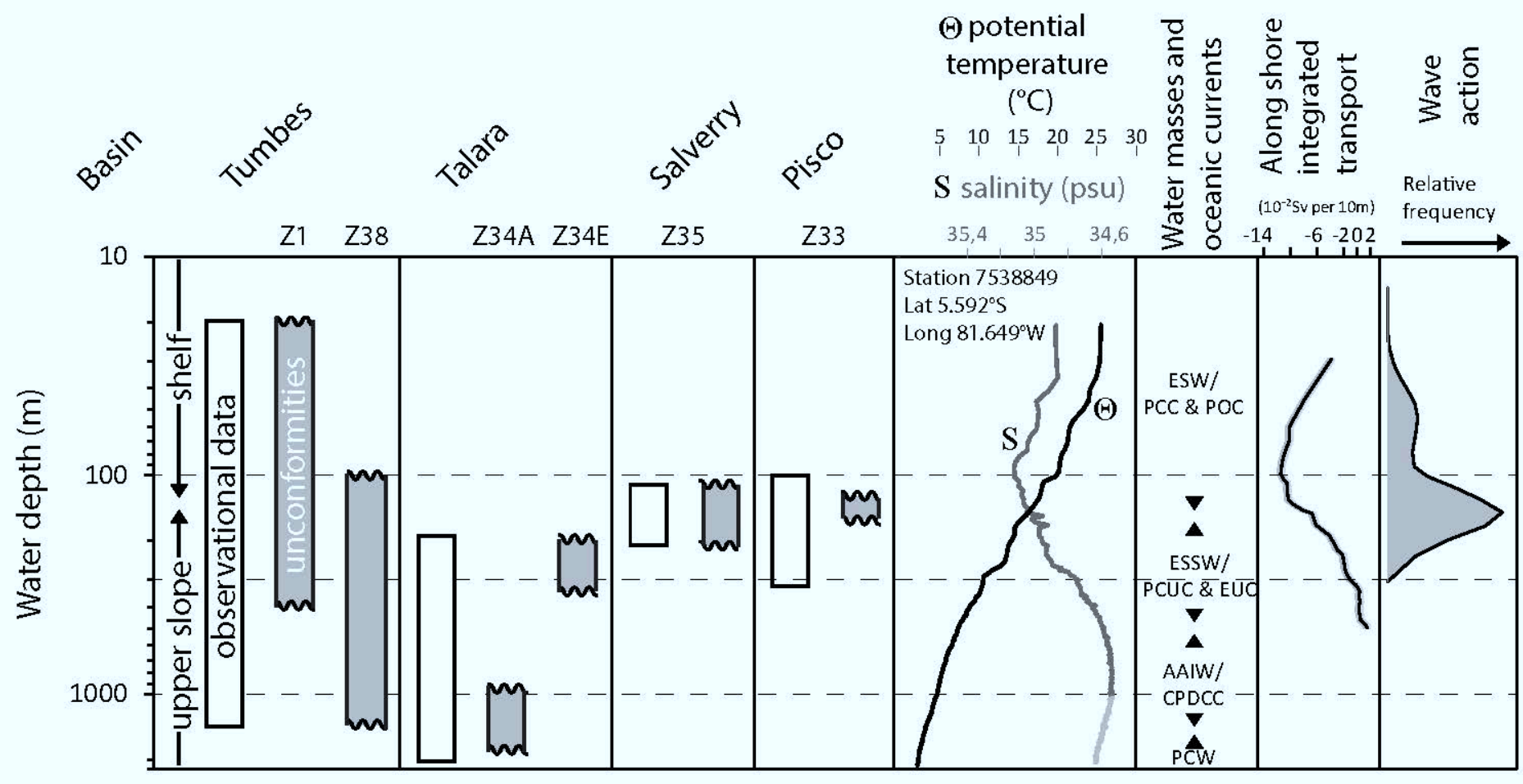




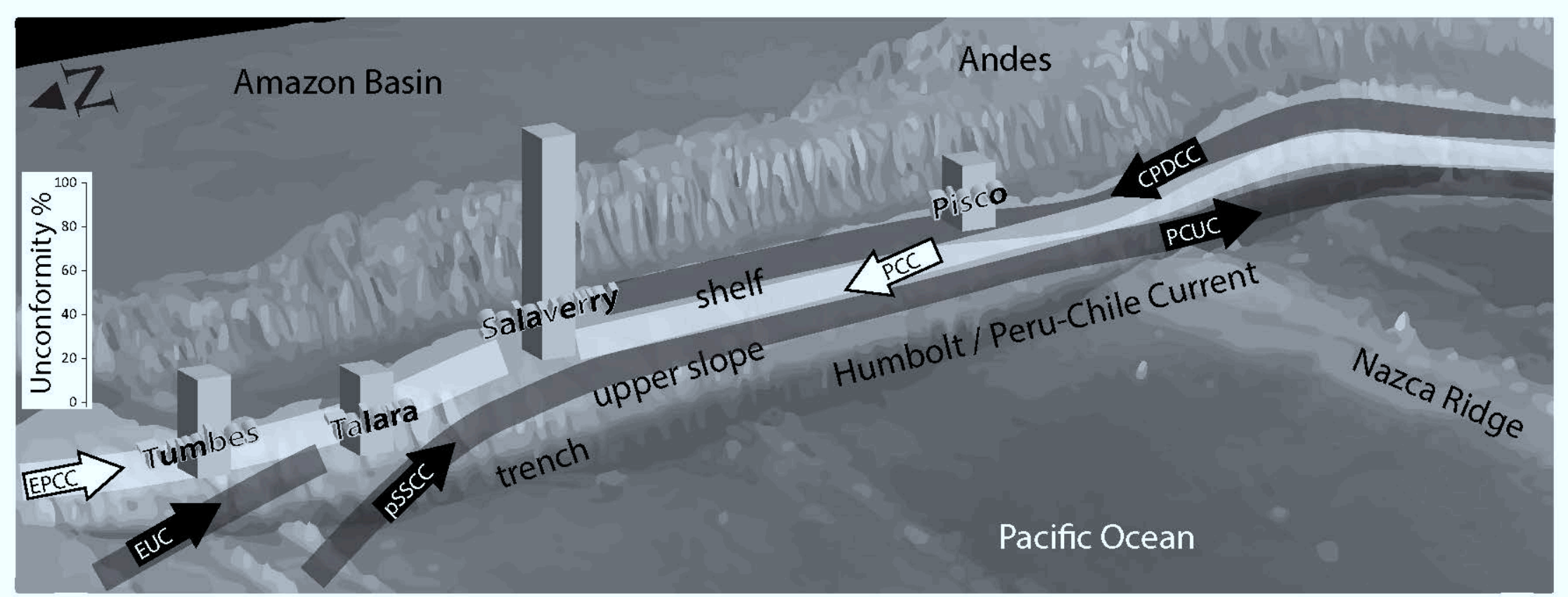


Table 1 : Geographical and morphological properties of the seafloor for the four sedimentary basins within the 3D seismic data volumes used for this study.

\begin{tabular}{|c|c|c|c|c|c|c|c|c|c|}
\hline \multirow[t]{2}{*}{ Sedimentary basin } & \multirow{2}{*}{$\begin{array}{c}\text { Dataset / } \\
\text { seismic cube }\end{array}$} & \multirow[b]{2}{*}{ Latitude } & \multicolumn{2}{|c|}{ Bathymetry } & \multirow{2}{*}{$\frac{\text { Survey area }}{\mathrm{km}^{2}}$} & \multirow{2}{*}{\begin{tabular}{|c|}
$\begin{array}{c}\text { Peak } \\
\text { frequency }\end{array}$ \\
$\mathrm{Hz}$ \\
\end{tabular}} & \multirow{2}{*}{$\begin{array}{c}\begin{array}{l}\text { Tuning thickness - } \\
\text { vertical resolution }\end{array} \\
\mathrm{m}\end{array}$} & \multirow{2}{*}{$\begin{array}{c}\text { Slope mean } \\
\text { (degree) }\end{array}$} & \multirow[t]{2}{*}{ Domain } \\
\hline & & & $\min (\mathrm{m})$ & $\max (\mathrm{m})$ & & & & & \\
\hline \multirow{2}{*}{ Tumbes } & $\mathrm{Z} 1$ & $3^{\circ} 45^{\prime} \mathrm{S}$ & 24 & 411 & 1300 & 40 & 10 & 3.6 & Shelf and upper slope \\
\hline & Z38 & $4^{\circ} 15^{\prime} \mathrm{S}$ & 99 & 1380 & 1620 & 43 & 9 & 2.6 & Shelf and upper slope \\
\hline \multirow{2}{*}{ Talara } & Z34A & $4^{\circ} 20^{\prime} \mathrm{S}$ & 946 & 1895 & 194 & 47 & 8 & 5.95 & Upper slope \\
\hline & Z34E & $5^{\circ} \mathrm{S}$ & 196 & 2040 & 215 & 35 & 11 & 10 & Shelf and upper slope \\
\hline Salaverry & Z35 & $8^{\circ} \mathrm{S}$ & 112 & 202 & 880 & 35 & 11 & 1.75 & Shelf \\
\hline Pisco & Z33 & $12^{\circ} 30^{\prime} \mathrm{S}$ & 108 & 323 & 663 & 32 & 12 & 1 & Shelf and upper slope \\
\hline
\end{tabular}
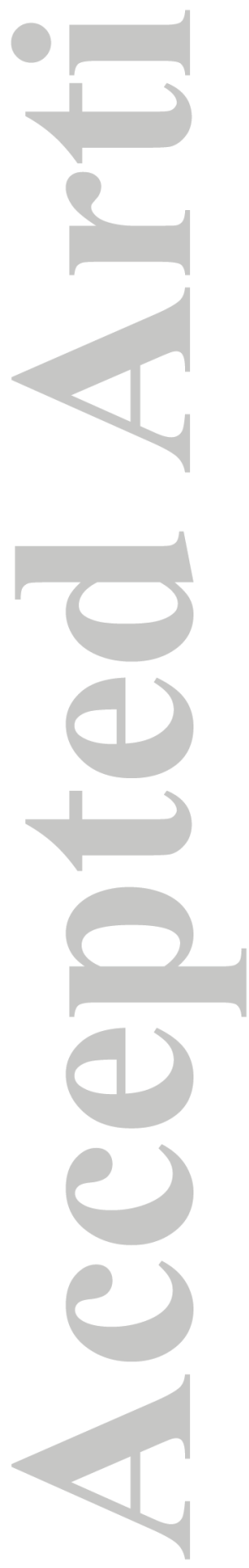

This article is protected by copyright. All rights reserved. 
Table 2: Morphological and seismic properties of the various features observed within the 3D seismic data volumes used for this study, and their interpretation.

\begin{tabular}{|c|c|c|c|c|c|c|c|c|c|}
\hline \multirow{2}{*}{$\begin{array}{l}\text { Sedimentary } \\
\text { basin }\end{array}$} & \multirow{2}{*}{$\begin{array}{l}\text { Dataset / } \\
\text { seismic cube }\end{array}$} & \multicolumn{4}{|c|}{ Feature/shape } & \multicolumn{3}{|l|}{ Interpretation } & \multirow{2}{*}{$\begin{array}{l}\text { Unconformity } \\
\% \\
(\text { minimum } / \text { mea } \\
\text { n/maximum) }\end{array}$} \\
\hline & & linear & rounded & mounds & \begin{tabular}{|l} 
flat top \\
high
\end{tabular} & Structural & Sedimentary & Fluid flow & \\
\hline \multirow{2}{*}{ Tumbes } & & $\mathrm{x}$ & $\mathrm{x}$ & $\mathrm{x}$ & & $\begin{array}{l}\text { faults / uplifted } \\
\text { structures }\end{array}$ & $\begin{array}{l}\text { erosional } \\
\text { unconformities, } \\
\text { contourite drift, }\end{array}$ & pockmarks & \multirow{2}{*}{$26 / 44 / 68$} \\
\hline & Z38 & $\mathrm{x}$ & $\mathrm{x}$ & $\mathrm{x}$ & $\mathrm{x}$ & $\begin{array}{l}\text { faults / uplifted } \\
\text { structures }\end{array}$ & $\begin{array}{l}\text { erosional } \\
\text { unconformities, } \\
\text { contourite drift, } \\
\text { moat }\end{array}$ & pockmarks & \\
\hline \multirow[t]{2}{*}{ Talara } & Z34A & $\mathrm{x}$ & $\mathrm{x}$ & $\mathrm{x}$ & $\mathrm{x}$ & faults & $\begin{array}{l}\text { erosional } \\
\text { unconformities, } \\
\text { head scarp of } \\
\text { mass wasting, } \\
\text { contourite drift, } \\
\text { channel, lobe }\end{array}$ & pockmarks & \multirow[t]{2}{*}{$18 / 36 / 53$} \\
\hline & Z34E & $\mathrm{x}$ & $\mathrm{x}$ & $\mathrm{x}$ & & fault & $\begin{array}{l}\text { erosional } \\
\text { unconformities, } \\
\text { canyons, } \\
\text { contourite drift }\end{array}$ & not identified & \\
\hline Salaverry & Z35 & $\mathrm{x}$ & $\mathrm{x}$ & & $\mathrm{x}$ & fault & $\begin{array}{l}\text { erosional } \\
\text { unconformities, } \\
\text { prograding } \\
\text { canyon infill, } \\
\text { canyon edges } \\
\end{array}$ & not identified & 100 \\
\hline Pisco & Z33 & $\mathrm{x}$ & & & $\mathrm{x}$ & not identified & $\begin{array}{l}\text { erosional } \\
\text { unconformities, } \\
\text { channels, wave } \\
\text { cut platform }\end{array}$ & not identified & 29 \\
\hline
\end{tabular}

